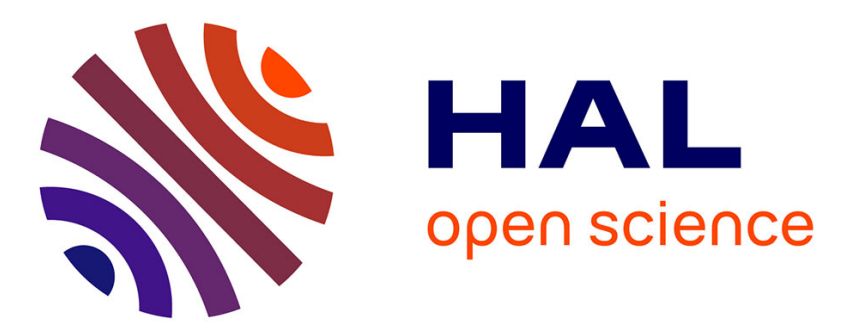

\title{
Chemical and textural equilibration of garnet during amphibolite facies metamorphism: The influence of coupled dissolution-reprecipitation
}

Tim J Dempster, Julie La Piazza, Andrew G. Taylor, Nicolas Beaudoin, Peter Chung

\section{To cite this version:}

Tim J Dempster, Julie La Piazza, Andrew G. Taylor, Nicolas Beaudoin, Peter Chung. Chemical and textural equilibration of garnet during amphibolite facies metamorphism: The influence of coupled dissolution-reprecipitation. Journal of Metamorphic Geology, 2017, 35 (9), pp.1111-1130.

10.1111/jmg.12278 . hal-02193025

\section{HAL Id: hal-02193025 \\ https://hal.science/hal-02193025}

Submitted on 24 Jul 2019

HAL is a multi-disciplinary open access archive for the deposit and dissemination of scientific research documents, whether they are published or not. The documents may come from teaching and research institutions in France or abroad, or from public or private research centers.
L'archive ouverte pluridisciplinaire HAL, est destinée au dépôt et à la diffusion de documents scientifiques de niveau recherche, publiés ou non, émanant des établissements d'enseignement et de recherche français ou étrangers, des laboratoires publics ou privés. 


\title{
Chemical and textural equilibration of garnet during amphibolite-facies metamorphism: The influence of coupled dissolution-reprecipitation
}

\author{
Tim J Dempster, Julie La Piazza, Andrew G Taylor, Nicolas Beaudoinn1,2, Peter Chung
}

1. School of Geographical and Earth Sciences, University of Glasgow, Glasgow G12 8QQ, UK

2. Department of Civil \& Environmental Engineering, University of Strathclyde, 75 Montrose Street, Glasgow G1 1XJ, UK

Corresponding Author Email ID: Tim.Dempster@glasgow.ac.uk

\begin{abstract}
Metamorphic equilibration requires chemical communication between minerals and may be inhibited through sluggish volume diffusion and or slow rates of dissolution in a fluid phase. Relatively slow diffusion and the perceived robust nature of chemical growth zoning may preclude garnet porphyroblasts from readily participating in low temperature amphibolitefacies metamorphic reactions. Garnet is widely assumed to be a reactant in staurolite-isograd reactions, and the evidence for this has been assessed in the Late Proterozoic Dalradian pelitic schists of the Scottish Highlands. Three-D imaging of garnet porphyroblasts in staurolitebearing schists reveal a good crystal shape and little evidence of marginal dissolution, however there is also lack of evidence for the involvement of either chlorite or chloritoid in the reaction. Staurolite forms directly adjacent to the garnet, and its nucleation is strongly associated with deformation of the muscovite-rich fabrics around the porphyroblasts. "Cloudy" fluid inclusionrich garnet forms in both marginal and internal parts of the garnet porphyroblast and is linked both to the production of staurolite and to the introduction of abundant quartz inclusions within the garnet. Such cloudy garnet typically has a Mg-rich, Mn-poor composition and is interpreted to have formed during a coupled dissolution-reprecipitation process, triggered by a local influx of fluid. All garnet in the muscovite-bearing schists present in this area is potentially reactive, irrespective of the garnet composition, but very few of the schists contain staurolite. The staurolite-producing reaction appears to be substantially overstepped during the relatively high pressure Barrovian regional metamorphism reflecting the limited permeability of the schists in peak metamorphic conditions. Fluid influx and hence reaction progress appear to be

This article has been accepted for publication and undergone full peer review but has not been through the copyediting, typesetting, pagination and proofreading process, which may lead to differences between this version and the Version of Record. Please cite this article as doi: $10.1111 /$ jmg. 12278
\end{abstract}

This article is protected by copyright. All rights reserved. 
strongly controlled by subtle differences in deformation history. The remaining garnet fails to achieve chemical equilibrium during the reaction creating distinctive patchy compositional zoning. Such zoning in metamorphic garnet created during coupled dissolution-reprecipitation reactions may be difficult to recognize in higher grade pelites due to subsequent diffusive reequilibration. Fundamental assumptions about metamorphic processes are questioned by the lack of chemical equilibrium during this reaction and the restricted permeability of the regional metamorphic pelitic schists. In addition the partial loss of prograde chemical and textural information from the garnet porphyroblasts cautions against their routine use as a reliable monitor of metamorphic history. However the partial re-equilibration of the porphyroblasts during coupled dissolution-reprecipitation opens possibilities of mapping reaction progress in garnet as a means of assessing fluid access during peak metamorphic conditions.

KEYWORDS: garnet, dissolution-reprecipitation, staurolite isograd, compositional zoning, permeability

\section{1 | INTRODUCTION}

Metamorphic phases equilibrate during prograde metamorphism via mineral reactions, however the direct evidence of the nature of the transformations is rarely preserved. This is largely due to reactions going to completion and the subsequent effective recrystallization of the remaining phases. As a consequence, reaction textures are typically lost. Theoretical constraints such as petrogenetic reaction grids (Albee, 1965; Harte \& Hudson, 1979; Spear \& Cheney, 1989) are frequently used to give an indication of the nature of individual isograd reactions, yet textural and chemical information to support these inferences and assess the processes by which metamorphic rocks equilibrate are often lacking or incomplete. Hence there is uncertainty in the mechanism of metamorphic reactions (Dohmen \& Chakraborty, 2003; Putnis \& John, 2010) and the equilibria responsible for development of many index minerals.

Garnet and staurolite typically appear within amphibolite-facies pelites as part of the prograde Barrovian metamorphic sequence (Barrow, 1893). The relationship between the two phases has been inferred through bulk rock chemical analysis (Pyle \& Spear, 2003), garnet zoning profiles (Whitney \& Ghent, 1993), phase diagram models (Connolly \& Petrini, 2002) and thin section textures (Martin et al., 2011). On the basis of these interpretations, in the absence of chloritoid in the precursor assemblage, it is widely assumed that garnet is partially consumed in the production of staurolite in typical Barrovian metamorphic sequences at $\sim 550^{\circ} \mathrm{C}$ and moderate pressure of 0.5-0.7 GPa, by the following net transfer dehydration reaction:

garnet+chlorite+muscovite $=$ staurolite+biotite+quartz+water (Florence $\&$ Spear, 1993).

Although a key reaction for defining amphibolite-facies conditions in pelites, there is typically a lack of direct evidence to constrain this theoretical isograd reaction. Indeed others have questioned the involvement of garnet in this reaction, noting the apparent lack of sufficient textural evidence for dissolution in the shape of the garnet porphyroblasts or chemical evidence from the internal zoning characteristics of garnet (Pattison \& Tinkham, 2009). The reaction was specifically selected for investigation because of the nearly ubiquitous assumption in classic

This article is protected by copyright. All rights reserved. 
texts on metamorphic petrology that this discontinuous reaction is responsible for staurolite growth (Frost \& Frost, 2014; Philpotts \& Ague, 2009) and indeed its suitability as a mappable isograd reaction (Bucher \& Frey, 1994; Philpotts \& Ague, 2009).

This study will test whether garnet chemically or texturally participates in a staurolite isograd reaction during amphibolite-facies regional metamorphism. Garnet is perhaps the most studied metamorphic mineral, apparently capable of preserving a range of important textural, chemical and temporal information on metamorphic histories and conditions (Baxter, Ague, \& Depaulo, 2002; Bell \& Johnson, 1989; Caddick, Konopásek, \& Thompson, 2010; Dempster, Symon, \& Chung, 2017; Holdaway 2001; Moynihan \& Pattison, 2013; Robyr, Darbellay, \& Baumgartner, 2014; Spear, Kohn, Florence, \& Menard, 1990; Spear, 2014; Thompson, Tracy, Lyttle, \& Thompson, 1977; Tracy, Robinson, \& Thompson, 1976; Yang \& Rivers 2001). It is characterized by relatively sluggish volume and grain boundary diffusion in lower amphibolitefacies conditions (Carlson, 2006; Dempster et al., 2017; Kohn, 2014). As a consequence the involvement of garnet in reactions involving diffusive exchange may be kinetically difficult in comparison to other minerals in these conditions. However in amphibolite-facies conditions coupled dissolution-reprecipitation has been reported as a mechanism for effectively changing garnet composition (Hames \& Menard, 1992; Martin et al., 2011; Whitney, Mechum, Dilek, \& Kuehner, 1996).

We apply a range of analytical techniques to assess the involvement of garnet as a reactant in a staurolite-producing reaction in the regional metamorphic Late Proterozoic Dalradian metasedimentary rocks from the Scottish Highlands. Garnet porphyroblasts are analysed to directly observe grain boundaries for surface textures and the internal zoning of the garnet porphyroblasts characterised using conventional traverses and X-ray mapping techniques. We document the shape of garnet porphyroblasts using X-ray computed microtomography and assess the mineralogical changes associated with the introduction of staurolite using thin section petrography.

\section{2 | GEOLOGICAL SETTING AND PREVIOUS WORK}

Five samples of the Leven schists from the Lochaber subgroup of the Appin group (Harris, Haselock, Kennedy, \& Mendum, 1994) in Glen Roy, Scotland (UK Ordnance Survey Grid Ref NN 2986185688 ) were collected from the same locality within a total of $\sim 2 \mathrm{~m}$ spacing of one another on the western bank of the River Roy. In most instances these samples are from continuous exposure and there is no evidence for any post metamorphic displacement between the sampled rocks. All samples appear very similar and are garnet-bearing muscovite-rich schists. The abundance of staurolite is variable between the samples ranging from $0-3.7 \%$. There are variable degrees of retrograde alteration that have generated up to $4 \%$ secondary chlorite after biotite. There are no quartz veins in the immediate vicinity of the sample sites. Typically the rocks from this area are recorded to be part of an extensive Barrovian garnet zone, as staurolite is rarely developed on a regional scale (Phillips et al., 1994). Fibrous sillimanite is locally present with staurolite within the Leven schists in upper Glen Roy, $10 \mathrm{~km}$ to the northeast of the sample site (J. Faithfull, pers. comm.).

This article is protected by copyright. All rights reserved. 
Regional metamorphism of the Glen Roy rocks was probably due to the Grampian Event, c. $480 \mathrm{Ma}$, in the early phase of the Caledonian Orogeny (Dempster et al., 2002; Oliver, Chen, Buchwaldt, \& Hegner, 2000), although the extent of earlier Precambrian metamorphism in the Dalradian block is uncertain (Dempster \& Jess, 2015). Previous studies have documented the structural evolution of the area and the timing of porphyroblast growth relative to these deformation phases (Phillips \& Key, 1992; Phillips et al., 1994). Peak metamorphic conditions are estimated at $\sim 500-600{ }^{\circ} \mathrm{C}, 0.7-0.8 \mathrm{GPa}$ (Phillips et al., 1994; Richardson \& Powell, 1976) and the lack of staurolite in these rocks is attributed to the scarcity of primary chlorite (Phillips et al., 1994). The absence of chloritoid from the vast majority of Dalradian pelites in lower grade assemblages, and specifically within the Leven schists from the Glen Roy area has been noted, either as a matrix phase or as inclusions within other porphyroblasts (Phillips \& Key, 1992). Whole rock analyses (e.g. Farber, Caddick, \& Timm, 2014) indicate that the rocks plot below the garnet-chlorite tie line in AFM projections, this together with the relatively high modal proportion of biotite to garnet indicate that chloritoid is probably not involved in the formation of staurolite. In addition, given the estimated relatively high pressures of Barrovian metamorphism in this location (Phillips et al., 1994), it is probable that chloritoid breakdown would occur at lower temperatures than the garnet-chlorite breakdown reaction (Droop \& Harte, 1995). On this basis we would predict that staurolite-bearing assemblages should contain most textural and chemical evidence of garnet dissolution, and based on AFM phase relationships contain more Mg-rich biotite and garnet compositions than the staurolite-free assemblages (Thompson, 1957).

\section{3 | PETROGRAPHY}

Relatively large (1-4 mm) abundant garnet porphyroblasts occur in a schistose matrix that is dominated by strongly aligned fine grained $(\sim 50-100 \mu \mathrm{m})$ muscovite, together with quartz and plagioclase (Figure 1a). Progressive deformation has formed an early S1 foliation and a dominant S2 foliation (Phillips et al., 1994). In all of the samples from this location a third deformation phase takes the form of open minor folds of the penetrative S2 cleavage. Staurolite when present typically forms small (up to $1.5 \mathrm{~mm}$ ) porphyroblasts in close proximity to garnet (Figure 1a). Primary chlorite is absent from any of the rocks examined in this study or by Phillips et al. (1994). Although some investigations have reported chlorite-bearing assemblages in the general vicinity (Farber et al., 2014), the textural descriptions and images presented of these rocks are suggestive of retrograde chlorite after biotite. Most samples show evidence of compositional layering with alternating muscovite- and quartzo-feldspathic layers of a few mmthickness. Assemblages and modal proportions of minerals in each of the analysed samples are presented in Table 1.

Two types of biotite are present in most samples including: porphyroblasts, which are typically equant 0.5-1 $\mathrm{mm}$ and contain sub-rounded quartz inclusions; and, smaller $(<0.5 \mathrm{~mm})$ aligned biotite (Figure 1a). The former are more commonly present in the quartz-rich areas, such as those near pressure shadows adjacent to garnet. The aligned biotite is typically present within the micaceous fabric domains that wrap around the garnet porphyroblasts. Retrogression of biotite to chlorite is patchy within the samples, often apparently concentrated in layers parallel to the fabric and is commonly associated with some dusty sericitization of plagioclase.

This article is protected by copyright. All rights reserved. 
Garnet forms euhedral to subhedral porphyroblasts (Figure 1b,c). Abundant quartz inclusions within the garnet often display a shape fabric and together with Fe-oxides may define straight or gently curving inclusion trails (Figure 1d). The porphyroblasts typically show areas of coarser $(\sim 100 \mu \mathrm{m})$ and finer $(<30 \mu \mathrm{m})$ quartz inclusions (Figure 1c). Inclusion trails with more abundant Fe-oxides typically lack abundant quartz and commonly align with matrix layers containing abundant muscovite and Fe-oxides. The inclusion trails are discordant to the dominant foliation, and record the earlier $\mathrm{S} 1$, although the outer rims $(20 \mu \mathrm{m})$ are relatively free from inclusions. Truncation of the internal porphyroblast fabric and S1 foliation curving around the garnets (Figure 1d) indicate syn-tectonic growth during S2 formation (Phillips \& Key, 1992). Microtextural evidence suggests that the garnet porphyroblasts nucleated within the quartz domains of the S2 cleavage and typically have pressure shadows containing coarser grained quartz. Garnet may be fractured predominantly perpendicular to the main S2 fabric. The porphyroblasts often have partially retrogressed biotite adjacent to the surfaces that faced S2 compressional stress (Figure 1b). In some samples irregular patches of the porphyroblasts may have a cloudy appearance characterised by micro-inclusions $(<1 \mu \mathrm{m})$. These cloudy areas are dark in thin section and typically associated with coarser grained and more irregular-shaped quartz inclusions than the non-cloudy equivalents (Figure 1c). In a few garnets with cloudy areas, coarse $(500 \mu \mathrm{m})$ biotite may also be partially enclosed within the garnet. Although many garnet porphyroblasts have euhedral margins some appear to be irregular in thin section view, especially in cases where the garnet is associated with coarse grained quartz (Figure 1c). This could be interpreted to indicate variable degrees of dissolution, although it is not consistent on all surfaces of individual crystals. Garnet may rarely show local partial alteration to chlorite either around its margins or associated with fractures, such retrogression is typically linked to patches showing more intense alteration of biotite in the matrix.

Staurolite appears to have formed in the mica domains of the dominant foliation in close proximity to garnet (Figure 1a). The anhedral to subhedral staurolite porphyroblasts $(0.25-1.5$ $\mathrm{mm}$ ) may contain elongate quartz inclusions aligned with the S2 fabric indicative of post tectonic growth. Staurolite locally shows evidence of marginal alteration with very fine grained rims of muscovite. Staurolite is often separated from adjacent garnet by thin ( 20-30 $\mu \mathrm{m})$, often partially retrogressed, biotite. There are no major differences in the mineral assemblages of the staurolite-bearing and staurolite-free schists, other than the presence or absence of staurolite. Thus modal proportions and sizes of garnet porphyroblasts are similar in all the samples (Table 1) and the only significant variation in modal mineralogy of the analysed rocks appears linked to the relatively abundant plagioclase in sample GR03 (21.1 modal \%) which is matched by lower than normal muscovite contents (Table 1). Opaque minerals have a modal abundance of up to $1.6 \%$, occur predominantly within the mica-rich areas of the matrix and are present as inclusions within all porphyroblasts.

\section{4 | METHODS}

Samples used for the analysis of in-situ grain boundaries were cut parallel to foliation into 1-3 $\mathrm{mm}$ slices, then fractured perpendicular to foliation to expose grain boundaries from the internal section of the rock. Following methods described in Dempster et al. (2017), fractured slices were mounted together in pairs using superglue, to ensure that previously adjoining pairs were side by side, effectively as mirror images. The samples were cleaned using an ultrasonic

This article is protected by copyright. All rights reserved. 
bath, then carbon coated for imaging and analysis on the FEI Quanta 200F Environmental Scanning Electron Microscope (SEM) with a $20 \mathrm{kV}$ voltage. The samples were examined using backscattered electron (BSE) and secondary electron (SE) images; to ensure the integrity of the grain boundary surfaces and characterise the mineral surfaces.

Large $(7 \times 5 \mathrm{~cm})$ polished thin sections for optical microscopy were prepared from homogeneous sections of the rocks. X-ray maps and compositional traverses were acquired using a Carl-Zeiss Sigma VP electron microscope operated at $20 \mathrm{kV}$, with Oxford Instruments XMax 80 energy dispersive spectrometry and data processed using Aztec Software 3.0. Images of thin sections were used for different spatial analysis techniques. The distance from each staurolite to the nearest garnet porphyroblast was recorded and then compared to a model based on a random staurolite distribution. The model was created by generating random numbers for an $\mathrm{X}, \mathrm{Y}$ coordinate system which was then superimposed on images showing the real distribution of garnet porphyroblasts. The angular position of staurolite in close proximity to garnet porphyroblasts was also assessed relative to the orientation of the micaceous fabric using the same thin sections.

The 3D morphology of garnet was assessed using X-ray computed microtomography imagery (XCT), a technique where the atomic density of material is converted to gray scale values. The 3D scans were collected on a Nikon XTH 320/225 system, equipped with a $225 \mathrm{kV}$ reflection gun, a micro-focus tungsten target, a $3 \mu \mathrm{m}$ laser spot size, and a $2000 * 2000$ cells flat panel photodetector (cell size $200 \times 200 \mu \mathrm{m}$ ). Part of a schist sample was scanned maintaining a source-to-sample distance to ensure the minimum voxel size $(3 \mu \mathrm{m})$. X-rays were produced from the interaction of an electron beam fired under a current of $28 \mu \mathrm{A}$ with an accelerating voltage of $100 \mathrm{keV}$ (resulting power $2.8 \mathrm{~W}$ ), and a W metallic target. The resulting scan consisted of 3141 projections captured during the complete rotation of the sample with an exposure time of $4 \mathrm{~s}$. To avoid photodetector saturation and ensure the best image quality, a 0.1 mm-thick $\mathrm{Cu}$ filter was used. Projections were overlapped in three different heights of the sample with CT Pro 3D software (@ 2004-2016 Nikon Metrology) to reconstruct the centre of rotation of the 3D volumes. Once reconstructed, a software built-in algorithmic correction has been applied to correct for artifacts related to beam-hardening (Brooks \& Dichiro, 1976).

The 3D volume was processed using Avizo software (v.9.0.1, (CFEI) to reconstruct the surfaces of a garnet porphyroblast (Figure 4). A garnet porphyroblast was selected at random from the scanned volume and the rest of the schist was cropped out. Noise was reduced using an edge-preserving smoothing filter ("bilateral filter") that averages the intensity value of a voxel with regard to the intensity value of its neighbours, considering a number of neighbours defined by a $3 \times 3 \times 3$ kernel size (3D interpretation). Based on atomic density, the garnet was isolated from other phases using a gray scale threshold function, and the cubic voxels at the surface of the garnet were transformed into a triangular meshed smooth surface wherein the details finer than 5 voxels $(15 \mu \mathrm{m})$ were lost.

This article is protected by copyright. All rights reserved. 


\section{5 | RESULTS}

\section{1 | Distribution and abundance of staurolite}

Spatial analysis of the staurolite-bearing schists shows that the distribution of staurolite is strongly linked to proximity to garnet porphyroblasts (Figures 1a and 2a) and typically occurs at distance of $<100 \mu \mathrm{m}$ from a garnet porphyroblast edge. The position of the staurolite at the porphyroblast edge is also strongly dependent on orientation relative to the S2 micaceous lithons (Figure 2b). This relationship is most clearly shown in sample GR03, which contains the lowest modal volume of staurolite and very small staurolite. In this sample staurolite typically forms at an angle of $\sim 60^{\circ}$ to the micaceous fabric and with a consistent asymmetry relative to the fabric orientation (Figure $2 \mathrm{~b}$ ). This relationship is less obvious in the schists containing larger and more abundant staurolite (Sample GR01; Figure 2b). However even in these rocks, staurolite is exceptionally rare within quartz-rich pressure shadow areas adjacent to garnet porphyroblasts and is nearly always associated with muscovite-rich layers that partially wrap the porphyroblasts. Staurolite is also absent from the muscovite-poor, plagioclase-rich layers within samples GR03. The spatial relationship between staurolite and garnet (Figure 2a) is sufficiently strong that it seems likely that in instances where staurolite occurs away from an immediately adjacent garnet it is probably an artifact of the 2D thin section. Larger and more numerous staurolite porphyroblasts occur in the matrix surrounded by clusters of garnet porphyroblasts (Figure 1a). Sample GR01 contains both the highest number of staurolite grains and a slightly higher proportion of staurolite at distance from garnet (Figure 2a), which appear to be preferentially concentrated close to biotite porphyroblasts. In the other staurolite-bearing samples there does not appear to be any correlation with staurolite abundance and position with respect to proximity to porphyroblastic biotite. Schists lacking staurolite are characterized by a virtual absence of cloudy garnet, whereas those containing staurolite have high proportions of cloudy garnet (Figure 3). The overall abundance of garnet does not correlate with staurolite abundance (Table 1).

\section{2 | Shape of garnet and surface characteristics}

In the staurolite-free schists, garnet is typically euhedral but in the staurolite-bearing samples some garnet has apparently embayed irregular crystal edges (Figure 1c). However the latter also contain many porphyroblasts that have euhedral geometry (Figure 1). The embayments in the subhedral garnet are typically filled with polycrystalline quartz and are often associated with positions adjacent to quartz-filled pressure shadows. XCT of individual porphyroblasts reveals the 3D geometry of the garnet and shows that in certain orientations, due to the abundance of quartz inclusions they may appear to be irregular shapes. However rotation of the scanned porphyroblast shows that even the most inclusion-rich parts of the porphyroblasts, which are potential candidates for dissolution, have good crystal shape in 3D (Figures 4a,b and S1).

The surfaces of the porphyroblasts in the staurolite-bearing schist were also investigated for evidence of small-scale dissolution using secondary electron images of the garnet surface. These typically reveal perfectly planar garnet surfaces with well-preserved step dislocations (Figure 4c). There is little evidence to suggest that irregular dissolution-related surfaces are present on the garnet. Locally the garnet surface is marked by regular well-shaped

This article is protected by copyright. All rights reserved. 
micron-scale pits, but these occur on otherwise flat surfaces of the porphyroblasts (Figure 4c) and there is no major disruption to the surface associated with these pits.

The garnet porphyroblasts in the staurolite-bearing schists lack evidence of dissolution either on a grain boundary scale or in terms of the overall shape of the porphyroblasts.

\section{3 | Nature and distribution of "cloudy" garnet}

Individual porphyroblasts in the staurolite-bearing schists may contain irregular zones of highly porous garnet (Figure 5a,b). Although they are exceptionally small, the presence of pits on electron images (Figures 4c and $5 \mathrm{~b}$ ) suggests that they are very likely to represent fluid-filled cavities (Figure 5c). Such zones of cloudy garnet but are either very rare or absent in schists that lack staurolite (e.g. GR02 and GR05). These inclusions may form in multiple aligned arrays within the garnet, which are of consistent orientations within an individual porphyroblast, indicative of a crystallographic control on their formation (Figure 5a). The fluid inclusion-rich cloudy garnet may comprise up to $\sim 60 \%$ of the total garnet population (Table 1 ). However the density and distribution of such fluid inclusions varies greatly between and within the samples. Adjacent porphyroblasts may be inclusion-free (clear) or inclusion-dominated (cloudy). Individual porphyroblasts typically have a patchy distribution of the fluid inclusion-rich zones. The textural relationship of the cloudy garnet to the host porphyroblast is most evident in those porphyroblasts that contain relatively small proportions of cloudy garnet. These patches appear to be related to either fractures cutting the porphyroblasts (Figure $5 \mathrm{c}, \mathrm{d}$ ) or discrete areas around the edges of the garnet. Such fractures may be open and quartz-filled (Figure 5c) or may be closed with no mineral fill. Both typically form at a high angle to the external fabric. In some instances cloudiness appears to be preferentially developed in zones where two garnet porphyroblasts are in contact or in close proximity. Garnet with the most intense cloudiness appears very dark in thin section view (Figure $5 d$ ) and reflect exceptionally high concentrations of fluid inclusions. In this garnet the cloudy patches take on a less systematic distribution. The garnet with high densities of fluid inclusions may show more late alteration to chlorite. However in most examples there is no link between the presence of cloudy garnet and the extent of local retrogression.

There is a strong correlation between the nature and size of the mineral inclusions in garnet and the development of cloudy garnet (Figure 6a). Cloudy garnet contains an average of 28 vol\% mineral inclusions in contrast to the clear garnet, which typically contains $10 \mathrm{vol} \%$ inclusions. The average size of the inclusions is also different with the cloudy areas of garnet porphyroblasts characterized by abundant large and irregular-shaped quartz inclusions, or more rarely plagioclase (Figure 6b-d). Non-cloudy garnet tends to show relatively welldeveloped mineral inclusion trails that define syn-tectonic geometries with the external fabric elements (Figure 1d). This geometry is poorly defined or absent in the parts of the porphyroblasts with areas of cloudy garnet (Figures 1c and 6d). The mineral inclusions within areas of cloudy garnet may have smooth scalloped-shaped contacts with the garnet host with thin bridges of garnet across quartz inclusions (Figure 6b). Although zones of larger quartz inclusions are also present in some of the porphyroblasts in staurolite-free schists (Figure 1d), these inclusions tend to be elongate and have relatively simple planar contacts with the host garnet. Typically the porphyroblasts dominated by cloudy garnet have thin $(<25 \mu \mathrm{m})$ clear rims lacking fluid inclusions immediately adjacent to quartz inclusions (Figure 6b).

This article is protected by copyright. All rights reserved. 
In two dimensions there does not appear to be any direct link between the location of zones of fluid-rich cloudy garnet within the porphyroblasts and the location of adjacent staurolite, although generally where larger or more abundant staurolite is present the adjacent garnet does contain relatively high proportions of cloudiness. The 3D geometry of the zones of fluid inclusion-rich garnet could not be assessed using the X-ray tomography due to insufficient density contrast with the clear garnet.

\section{4 | Garnet zoning characteristics}

Major element zoning profiles and compositional maps of garnet from both staurolite-bearing and staurolite-free schists were obtained. In addition X-ray maps from porphyroblasts with patchy development of cloudy garnet were also gathered. Typically characteristic bell-shaped Mn-profiles (Hollister, 1966) are present in garnet porphyroblasts from staurolite-absent assemblages with $\mathrm{Mg} / \mathrm{Fe}$ ratios increasing from $\sim 0.04$ in the core to $\sim 0.12$ in the rim (Figure 7). These porphyroblast cores typically contain $>10 \%$ spessartine (Figure $7 \mathrm{~b}$ ).

The zoning patterns are less clearly defined for garnet in staurolite-bearing schists (Figure 8). The same general pattern of zoning appears to be present in the porphyroblasts containing patches of cloudy garnet with elevated spessartine contents in the central areas (Figure 8c,f). However elevated Mg contents, with high $\mathrm{Mg} / \mathrm{Fe}$ of $\sim 0.1$, characterise the cloudy garnet areas towards the core of the porphyroblasts (Figure 8d,f). These are typically coupled to higher Fe contents, and Ca- and Mn-contents that are $40-50 \%$ lower than the equivalent central areas of clear garnet porphyroblasts (Figure 8e,f). Most of these compositional characteristics occur in areas that match the textural changes associated with cloudy garnet, irrespective of the geometry of the cloudy area and its location within the porphyroblast. The composition of the garnet does not show sharp transitions between cloudy and clear garnet but smooth gradual compositional changes occur over a distance of 50-150 $\mu \mathrm{m}$ associated with these boundaries (Figure 9). The transitions in Mg and Mn are smoother for than for Fe and Ca (Figure 9), with the latter typically showing the least regular variation (cf. Carlson, 2002). Away from such edge effects, the composition of cloudy garnet is not consistent within a single porphyroblast, although generally systematic differences between the immediately adjacent clear garnet and the cloudy garnet are observed (Figure 8f). The cloudy garnet in the core of the porphyroblasts appears to be consistently Mn-poor relative to the adjacent clear garnet, whereas cloudy garnet close to the porphyroblast rim is typically slightly more Mn-rich in comparison to the adjacent clear garnet (Figure 8f). Other divalent cations show less pronounced but systematic differences in composition that are linked to position of the cloudy garnet within the host porphyroblast (Figure 8). Overall cloudy garnet compositions tend to mimic the zoning in the host porphyroblast but with a lower amplitude of variation. The increased $\mathrm{Mg} / \mathrm{Fe}$ composition of porphyroblasts in areas of cloudy garnet is generally compatible with higher temperature conditions (Ferry \& Spear, 1978; Thompson, 1976) as might be expected from a prograde staurolite-producing reaction. The M/FM composition of garnet rims in the staurolite-bearing and staurolite-free schists is indistinguishable $(0.100 \pm 0.004(n=18)$ and $0.097 \pm 0.005(n=13)$ respectively). Garnet porphyroblasts may show local increases in Mn-content associated with their outer rims $(30 \mu \mathrm{m})$ (Figure 8f). Mn-contents of staurolite are below detection limits of energy dispersive spectrometry in these rocks and $\mathrm{Zn}$ contents are similarly low.

This article is protected by copyright. All rights reserved. 


\section{6 | INTERPRETATION}

\section{1 | Theoretical staurolite-producing reactions}

Virtually all staurolite-producing reactions in pelites that have previously been suggested are believed to consume chlorite (e.g. Florence \& Spear, 1993; Novak \& Holdaway, 1981; Pattison \& Tinkham, 2009; Phillips \& Key, 1992; Spear, 1988; Spear, 1991) and or chloritoid (e.g. Albee, 1972; Baltatzis, 1979; Karabinos, 1985; Whitney \& Ghent, 1993). Whilst it is conceivable that primary chlorite was previously locally abundant in the staurolite-bearing assemblages of this study, the staurolite-bearing schists provide no textural or geochemical evidence to support this suggestion. The abundance of garnet-biotite assemblages in the Leven Schists and the associated absence of primary chlorite may be a reflection of a general higher pressure Barrovian sequence (Dempster \& Harte, 1986). This is a consequence of the relative slopes of the chlorite-consuming, garnet-producing reaction and the garnet-chlorite breakdown reaction in $P$-T space (Harte \& Hudson, 1979). No chloritoid has been reported in the Leven schist at lower grades elsewhere in the Scottish Highlands. Hence there is no evidence for the involvement of either chlorite or chloritoid in this reaction. This, coupled to the lack of marginal dissolution of garnet, suggests that most of the predicted isograd reactions based on AFM graphical relationships (Thompson, 1957) are inappropriate to explain the production of staurolite in these pelites. Such graphical techniques suggest that garnet and chlorite react in a discontinuous reaction (in KFMASH systems) to produce staurolite in regionally metamorphosed pelites. This involves the following reaction:

$6 \mathrm{Grt}+13 \mathrm{Ms}+4.6 \mathrm{Chl}=2 \mathrm{St}+13 \mathrm{Bt}+23 \mathrm{Qz}+14.8 \mathrm{H}_{2} \mathrm{O}($ Farber et al., 2014)

Based on this balanced reaction, the molar volumes of garnet and staurolite (Geiger \& Feenstra, 1997; Holdaway, Guidotti, Novak, \& Henry, 1995) and the modal mineralogy of the schists (Table 1), the formation of $~ 3.7$ vol\% staurolite in sample GR01 would be associated with consumption of more than $2.8 \mathrm{vol} \%$ of the garnet previously present in the schist. This equates to approximately $35 \%$ of existing garnet being consumed in the schists. The textural evidence of this amount of garnet dissolution should in theory be obvious and might be associated with significantly higher Mn contents at the edges of affected porphyroblasts (Kohn \& Spear, 2000; Tuccillo, Essene, \& van der Pluijm, 1990). Despite the apparently irregular margins characteristic of some of the poikiloblasts, dissolution is difficult to prove in 2D thin section, as the porphyroblast geometry is uncertain (Figure 1). However 3D evidence from XCT scanning suggests that no major marginal dissolution of garnet occurs (Figures 4 and S1). Given equilibrium AFM phase relationships, garnet in an assemblage with staurolite and biotite should be Mg-rich in comparison to those from garnet-biotite assemblages at the same metamorphic grade (Whitney \& Ghent, 1993). Garnet rim compositions of staurolite-bearing and stauroliteabsent assemblages are indistinguishable and so such relationships also fail to support a chlorite-breakdown reaction to account for the appearance of staurolite.

Pattison \& Tinkham (2009) attributed the lack of garnet involvement at the staurolite isograd as being due to sluggish garnet dissolution and/or a cascade effect linked to the release of fluids in other reactions causing multiple reactions to occur at similar conditions. They argued that reactions failed to maintain equilibrium in a contact metamorphic setting and that fractional crystallization and effective isolation of garnet occurred within the whole rock. These authors suggested $\mathrm{Ms}+\mathrm{Chl}=\mathrm{St}+\mathrm{Bt}$ as a probable isograd reaction and speculated that with the

This article is protected by copyright. All rights reserved. 
longer timescales associated with regional metamorphism there would be greater opportunity for the garnet to behave as an open system.

\section{2 | Garnet involvement in the staurolite-producing reaction}

The location of new staurolite growth is strongly linked to the presence of both muscovite and garnet porphyroblasts (Figure 2a). As such the garnet porphyroblasts must have a chemical and/or mechanical role in the staurolite-producing reaction. Staurolite is particularly abundant around garnet especially where garnet itself is clustered (Figure 1a). The systematic relationship between the staurolite and the orientation of the fabric (Figure 2b) suggests that structural controls are also important in controlling the location of staurolite growth. This may be a reflection of strain partitioning into the micaceous domains adjacent to the garnet (Bell \& Hayward, 1991; Groome, Johnson, \& Koons, 2006). The staurolite appears to nucleate at a consistently oblique angle to the S2 cleavage. This implies that an element of shear was involved in the nucleation process, with deformation at the margins of the garnet being most intense at $60^{\circ}$ to the cleavage orientation. This relationship is progressively obscured associated with continued growth of staurolite (sample GR01), but in part this may be related to the uncertainty in estimating the initial nucleation sites of larger staurolite grains.

The potential involvement of biotite in the reaction is indicated by the post-S2 growth of porphyroblasts. However biotite abundance is not strongly linked to the amount of staurolite that is present and indeed such porphyroblastic biotite also occurs in samples lacking staurolite.

\section{3 | Formation of cloudy garnet via coupled dissolution-reprecipitation}

The formation of cloudy garnet with pervasive apparently crystallographically-controlled (cf. Martin et al., 2011) fluid inclusions (Figure 5a) implies that the garnet is modified by a coupled dissolution-reprecipitation mechanism (Putnis \& Austrheim, 2010; Putnis \& Putnis, 2007; RuizAgudo, Putnis, \& Putnis, 2014). Similar fluid inclusion-rich garnet has also been reported in other studies, typically forming associated with either marginal alteration, or proximity to inclusions or fractures (Erambert \& Austrheim, 1993; Hames \& Menard, 1993; Martin et al., 2011; Pollok, Lloyd, Austrheim, \& Putnis, 2008; Whitney et al., 1996; Yardley, 1977). Although most of these studies have not linked its formation to particular mineral reactions, cloudy garnet appears to be relatively commonly reported in staurolite-bearing assemblages in pelites (Hames \& Menard, 1993; Martin et al., 2011; Whitney et al., 1996).

The correlation of staurolite abundance with the appearance of cloudy garnet (Figure 3) and the change in chemistry of the garnet in these zones (Figure 8f) provides evidence that garnet is chemically involved in the production of staurolite. Garnet reaction sites are typically associated with fractures and the edges of porphyroblasts. Larger garnet crystals are less prone to modification presumably as they have proportionally less edge. The localized patchy nature of the reaction and the nature of the coupled dissolution-reprecipitation process itself, imply that fluids play a significant role in controlling the reaction. It appears that once started the reaction progresses in that same location and as such appears to be self-perpetuating (Cartwright, 1997), until perhaps all the locally available fluid is exhausted and or fluid pathways are sealed. A trigger for the dissolution-reprecipitation process appears to be required providing fluid access either at the porphyroblast edge or associated with fracture systems within garnet (Whitney, 1996). These textural sites for the reaction, together with the nucleation of staurolite in sites (Figure $2 \mathrm{~b}$ ) where strain would be focused around the edge of

This article is protected by copyright. All rights reserved. 
the garnet porphyroblast (Bell \& Hayward, 1991), both indicate that deformation is a crucial component in allowing the reaction to occur (Dempster \& Tanner, 1997). Thus deformation, and perhaps the fracturing of garnet (Whitney, 1996), allows the fluid access to then enable the coupled dissolution-reprecipitation process. Once initiated the replacement process may itself create stresses that allow further influx of fluids to the reaction sites (Centrella, Austrheim, \& Putnis, 2015).

The geometry of the chemically-modified zones is very irregular and appears to be linked to garnet volume loss through the introduction of more abundant and coarser grained quartz inclusions (Figure 6b). Thus the coupled dissolution-reprecipitation processes not only involve a change in garnet composition but also a partial replacement by quartz. Original variation in the size, shape and abundance of quartz inclusions could set up stresses within the porphyroblast by differential expansion (Whitney, 1996; Whitney, Cooke, \& Du Frane, 2000) and allow subsequent fracturing and fluid access to the garnet. However the characteristics of these zones, such as: degradation of the internal fabric relationships; the different geometry of the inclusion/host interfaces; and, the link to the high $\mathrm{Mg} / \mathrm{Fe}$ geochemistry of the garnet (Thompson, 1976) all point towards a high temperature late prograde origin for the cloudy garnet.

\section{4 | Staurolite-forming reaction in the Leven schist}

The formation of staurolite appears to involve garnet and muscovite as reactants and the introduction of fluids. The reaction:

2.58 Alm+1.9 Ms+1 $\mathrm{H}_{2} \mathrm{O}=1 \mathrm{St}+1.9 \mathrm{Bt}+5 \mathrm{Qz}$ (Thompson, 1976; Tracy et al., 1976);

may be relatively insensitive to temperature change and will typically be associated with falling pressure (Holdaway et al., 1982; Novak \& Holdaway, 1981; Thompson, 1976). As such it may be commonly associated with $P$ - $T$ changes that occur near peak regional metamorphic amphibolite-facies conditions (England \& Thompson, 1984). A small amount of water is required as a reactant to balance the hydrous structural component in staurolite and allow staurolite to form without invoking the involvement of chlorite or chloritoid. This reaction has the potential to form staurolite in pelites within the garnet-biotite assemblages lacking chlorite that are commonly generated in garnet zone conditions. Given the molar volumes of garnet and staurolite (Geiger \& Feenstra, 1997; Holdaway, Mukhopadhyay, \& Dutrow, 1995) this reaction for the Fe-end member would account for roughly $1.5 \mathrm{vol} \%$ staurolite for every $1 \mathrm{vol} \%$ of garnet consumed. The increase in volume of quartz inclusions associated with garnet replacement provides a rough estimate of the volume loss of garnet in the production of staurolite. Based on observed volumes of quartz inclusions within cloudy garnet (Figure 6a) this would equate to the formation of roughly $5.5 \mathrm{vol} \%$ cloudy garnet (Figure 3). Calculation of these volumes is complicated by the difficulty in constraining a consistent "equilibrium" garnet composition for the reaction. However it is also evident from the distribution of the cloudy garnet that this alteration process is independent of the original composition of the garnet.

As part of the reprecipitation process garnet consistently becomes more Mg-rich, which would be associated with increasing temperatures (Thompson, 1976), and is typically depleted in both $\mathrm{Mn}$ and Ca. However the chemistry of the new garnet that forms from the reaction is difficult to constrain due both to its variability depending on position within the host porphyroblast and subsequent diffusive modification across the boundary (Florence \& Spear,

This article is protected by copyright. All rights reserved. 
1991; Mueller, Watson, \& Harrison, 2010). The lack of a tight correlation between the production of staurolite and either the abundance of cloudy garnet (Figure 3 ) and or the proportion of new biotite growth may suggest that on the metre-scale of sampling in this investigation there is an element of open system behaviour for some of the more mobile components (Carmichael, 1969).

\section{7 | DISCUSSION - BEHAVIOUR OF GARNET DURING METAMORPHISM}

\section{1 | Garnet as a monitor of permeability during metamorphism}

Garnet reacts via coupled dissolution-reprecipitation irrespective of whether it is a core or rim composition and as such all existing garnet is unstable with muscovite and fluid in these peak metamorphic staurolite zone conditions. The persistence of garnet must reflect a lack of fluid, which would act both as a missing reactant and a kinetic impediment to the reaction. This indicates that there is inherently very limited permeability in such mid-crustal conditions (Rubie, 1986; Yardley, 2009) and common assumptions of the presence of fluid during prograde metamorphism (e.g. Etheridge, Wall, \& Vernon, 1983; Ferry, 1994; Masters \& Ague, 2005) do no hold in these rocks.

We conclude that all garnet-muscovite schists in the vicinity would develop staurolite provided that fluid was available during the peak metamorphic conditions. In the schists from Glen Roy, deformation appears to provide the trigger to allow fluid access and start the coupled dissolution-reprecipitation process. Some of the textural evidence suggests that fluid ingress is linked to fracturing of garnet, such that tensile fractures may play a role in drawing in fluids and allowing reactions (Jamtveit, Putnis, \& Malthe-Sørenssen, 2009). All of the immediately adjacent samples share a deformation history, but crucially not all share the reaction history. As such the assemblage changes appear to reflect subtle local controls on permeability. Future work might focus on mapping reaction progress (e.g. Skelton, Graham, \& Bickle, 1995), via coupled dissolution-reprecipitation generated zoning in garnet, to provide an understanding of $\mathrm{m}$-scale controls on permeability during prograde metamorphism.

The fluids involved in this reaction could be sourced from prograde reactions occurring at depth. Such fluids would be predicted to migrate along veins (e.g. Whitney et al., 1996) and could potentially trigger coupled dissolution-reprecipitation reactions in the rocks through which the fluids pass. However in this instance vein structures are lacking from the immediate vicinity and discrete channels are not obvious. There is a possibility that the lithological uniformity of the Leven schist succession plays a part in the preservation of these disequilibrium reaction textures. A more complex heterogeneous sequence of lithologies will inevitably contain a range of mineral assemblages, which would experience a series of dehydration reactions during prograde metamorphism. Such sequences may act as more continuous sources of fluids that may infiltrate into adjacent lithologies, trigger reactions and allow equilibration. In addition local rheological contrasts in more variable lithological successions may create differing structural responses and facilitate fluid ingress.

This article is protected by copyright. All rights reserved. 


\section{2 | Disturbance to garnet porphyroblast zoning and textures}

Garnet porphyroblasts are often thought to be relatively robust and faithfully preserve internal fabrics and chemical evidence of the evolution of $P$ - $T$-t conditions (e.g. Bell \& Hayward, 1991; Caddick et al., 2010; Moynihan \& Pattison, 2013). However processes associated with the introduction of staurolite significantly degrade all elements of this record. The compositions of the modified zones are variable and appear to be partially inherited from the host porphyroblast. As such the coupled dissolution-reprecipitation process creates significant chemical disequilibria within garnet porphyroblasts. If these compositions were then used in techniques that assume equilibrium growth (e.g. Moynihan \& Pattison, 2013; Spear et al., 1990), misleading histories would result. It is notable that this disequilibrium is generated in the presence of a fluid phase (cf. Carlson, Pattison, \& Caddick, 2015), a factor commonly assumed to enhance equilibrium. Thus it is not just diffusive re-equilibration that is capable of disturbing compositional growth zoning profiles in garnets (e.g. Dempster, 1986; Mueller et al., 2010), coupled dissolution-reprecipitation may play an important role (Erambert \& Austrheim, 1993; Kohn, 2014; Martin et al., 2011).

The crystallization of cloudy garnet is one of the primary fingerprints of the coupled dissolution-reprecipitation process. This is linked to the generation of irregular cross-cutting internal compositional zones (Figure 8), controlled by fluid access (Erambert \& Austrheim, 1993), together with formation of large, abundant and irregular-shaped quartz inclusions (Figure 6). In theory, such processes could affect all garnet-muscovite bearing assemblages and are hence capable of influencing the internal compositional zoning in all existing garnet porphyroblasts in pelites. Some initial modification of garnet appears to be linked to the formation of fractures (i.e. GR05) (e.g. Whitney, 1996), but where there is more staurolite growth the reaction appears to focus on marginal locations within the garnet porphyroblasts (i.e. sample GR01). There is a danger of such patchy zoning being misinterpreted as ineffective grain boundary diffusion (Dempster et al., 2017) and overprint zoning (Hirsch, Prior, \& Carlson, 2003). There are many of examples of compositional zoning patterns apparently linked to quartz inclusion size and/or the presence of fluid inclusions (e.g. Carlson, Hixon, Garber, \& Bodnar, 2015; Ríos, Castellanos, \& Takasu, 2010). Such zoning could be interpreted as the operation of coupled dissolution-reprecipitation reaction processes.

Whether the reaction identified here is widely responsible for staurolite growth in pelites is uncertain, although it is notable that cloudy garnet appears to be commonly associated with staurolite-bearing pelites (e.g. Hames \& Menard, 1993; Whitney et al., 1996). In the absence of primary chlorite and chloritoid, staurolite formation may be linked to the formation of patchy compositional zoning in garnet, hence such irregular garnet zoning might be a characteristic of Fe-rich chlorite-poor pelites in amphibolite-facies conditions.

Localized coupled dissolution-reprecipitation of porphyroblasts also has major implications for the preservation of garnet porphyroblast inclusion textures. Although there may be issues with the interpretation of microstructural evidence from porphyroblasts (Vernon, White, \& Clarke, 2008), the traditional view (e.g. Farber et al., 2014; Zwart, 1962) is that inclusions trapped as overgrowths during porphyroblast growth preserve a robust record of growth in their geometry and inclusion types. However subsequent formation of abundant quartz inclusions results in loss of the geometry of original inclusion trails established during initial garnet growth. No major degradation in porphyroblast shape occurs (Centrella et al.,

This article is protected by copyright. All rights reserved. 
2015), so overall garnet crystal form remains dominant and as such the later recrystallization is not immediately obvious. Consequently significant textural modification of the interior of porphyroblasts is possible. This process also provides a potential mechanism by which inclusions formed at higher temperature (e.g. staurolite and biotite) may be incorporated into lower temperature host porphyroblasts (e.g. garnet) (e.g. Farber et al., 2014).

Isotopic resetting may be an additional consequence of the coupled dissolutionreprecipitation process (Erambert \& Austrheim, 1993; Kohn, 2014). Hence internal rejuvenation of isotopic systems within garnet potentially may take place creating apparently little difference between the isotopic ages of the internal and external portions of porphyroblasts. Unless such processes can be ruled out apparently exceptionally quick regional metamorphic histories might be inferred (cf. Baxter et al., 2002; Oliver et al., 2000) associated with "implausible" (Connolly, 2010) rates of heating.

\section{3 | Garnet growth zoning and Mn partitioning}

The Mn growth zoning in garnet is commonly attributed to Rayleigh fractionation processes (Hollister, 1966) involving progressive depletion of Mn from the matrix phases (but see Hirsch et al., 2003; Zeh, 2006). Thus processes involved in the consumption of garnet are typically associated with incorporation of Mn back into the remaining garnet. This is believed to generate the commonly reported Mn-rich rims linked to retrogression (Carlson, 2002; de Béthune, Laduron, \& Bocquet, 1975; Kohn \& Spear, 2000). The results of this investigation indicate that garnet consumption occurs in a high temperature prograde reaction. However within the core of the original porphyroblast, the new garnet that forms in this reaction typically has a lower Mn content than the original unmodified porphyroblast (Figure 9) despite the net consumption of garnet. Hence particularly in the porphyroblast core areas Mn appears not to be partitioned straight back into the reprecipitated garnet (Figure 8f). Although complicated by the lack of equilibrium in the garnet compositions, the observation has implications for models of the behaviour of Mn during garnet growth. This indicates that partition coefficients between matrix and garnet must be temperature sensitive. Hence the typical bell-shaped Mn-distribution associated with prograde garnet growth zoning (Kohn, 2014) may form not solely through progressive depletion of the Mn in the matrix (Hollister, 1966) but by enhanced Mn partitioning into garnet at lower temperatures. As such Mn-rich rims to garnet are not a reliable means of inferring dissolution of garnet (e.g. Kohn, 2014) but may simply be indicative of diffusive low temperature re-equilibration with matrix phases.

\section{4 | Re-equilibration of garnet in high-grade conditions}

The prograde staurolite-producing reaction imposes characteristic irregularities on the existing porphyroblast zoning patterns. At slightly higher temperatures than those associated with the growth of staurolite, volume diffusion of key cations in garnet typically starts to become very effective (Carlson, 2006; Ganguly, 2010). Hence such irregularities are typically absent from most high-grade garnet (Kohn, 2014). It is notable that Ca shows the most irregular zoning within the cloudy garnet zones and this may reflect limited diffusive re-equilibration of this cation (Chernoff \& Carlson, 1997). Consequently the fingerprints of coupled dissolutionreprecipitation are readily lost in higher grade conditions through a combination of subsequent heating and preservation of overall porphyroblast shape. Cloudy garnet is also unlikely to survive into high grade conditions as fluid inclusions are lost (Putnis, Tsukamoto, \& Nishimura,

This article is protected by copyright. All rights reserved. 
2005). Such loss is evident from the thin fluid-poor rims at the edges of porphyroblasts and in garnet surrounding mineral inclusions that are observed in both this study and elsewhere (Martin et al., 2011; Whitney et al., 1996). Consequently there is perhaps only a narrow window of conditions in which either obvious chemical or textural evidence of this coupled dissolutionreprecipitation process in garnet is readily preserved in amphibolite-facies pelites.

\section{8 | IMPLICATIONS FOR METAMORPHIC EQUILIBRATION}

Coupled dissolution-reprecipitation provides a reaction mechanism that happens in a rather haphazard way, seemingly affecting various parts of the original zoned porphyroblasts. Either the reaction is completely independent of garnet composition or it is sufficiently overstepped when fluid infiltration occurs that all garnet compositions will potentially react. In theory, the staurolite-producing reaction identified in this study should be dependent on garnet composition with garnet stability extended to lower pressures by the presence of $\mathrm{Mn}$ (Holdaway et al., 1982; Mahar, Baker, Powell, Holland, \& Howell, 1997). This may be partially countered by the effects of Zn on staurolite stability (Guidotti, 1970), although Zn contents are low in these rocks. In the absence of fluids, garnet will be essentially inert and the timing of fluid access is thought likely to be crucial and result in significant overstepping. Therefore it is only during periods of enhanced permeability that reaction and coupled dissolution-reprecipitation occurs and it is the location of those fluids that appears to control reaction progress. Structurally-controlled mechanisms, allowing small volumes of fluids to gain access to the garnet, appear crucial for this reaction to occur. It is interesting to note that it appears that similar access routes appear to have subsequently been used as pathways for late retrograde fluids. Such garnet breakdown reactions provide unique opportunities to study permeability in prograde regional metamorphism, and test common assumptions of fundamentally different behaviour during retrograde and prograde metamorphic processes (Jamtveit \& Austrheim, 2010).

Limited fluid availability in these schists appears to be the dominant control on staurolite formation. Indeed disequilibrium peak metamorphic assemblages lacking staurolite in pelites are dominant in the presumably fluid-absent conditions in this area. In terms of commonly assumed fluid-present conditions during prograde metamorphism (e.g. Ferry, 1994) these represent disequilibrium assemblages and such kinetic paralysis may then impact on further mineralogical changes. Thus the absence of staurolite would obviously then inhibit kyanite formation (Chinner, 1965). Garnet breakdown reactions such as this with low reaction affinity have the potential to create significant cascade effects following overstepping (Kelly, Carlson, \& Ketcham, 2013; Pattison, De Capitani, \& Gaidies, 2011) associated with fluid influx triggered by deformation.

There is a common assumption that the long time scales, presence of fluids and active deformation associated with regional metamorphism will allow equilibrium (e.g. Pattison \& Tinkham, 2009). These assumptions may be flawed. The lack of chemical equilibrium also questions the applicability of traditional graphical schemes for identification of metamorphic reactions, especially those involving reactant phases where volume and grain boundary diffusion is sluggish (Dempster et al., 2017) and participation may be kinetically difficult. This inevitably leads to the question of how common the coupled dissolution-reprecipitation

This article is protected by copyright. All rights reserved. 
processes identified in this study are, and hence how applicable the conclusions are to other situations. Such characteristics crucially apply to garnet behaviour in staurolite- and kyanitezone Barrovian metamorphism, perhaps particularly in relatively high pressure conditions. It is uncertain whether this reaction type is restricted to those involving garnet consumption. This seems unlikely and garnet may be simply better at preserving the evidence than other phases, such as plagioclase and muscovite, which are similarly characterized by sluggish volume diffusion in lower amphibolite-facies conditions (Dempster, 1992).

Despite the acknowledged importance of the staurolite-isograd reaction in pelites as defining a major facies boundary (cf. Carlson et al., 2015), it is widely assumed both that chlorite and or chloritoid are involved in the reaction, and that garnet dissolution occurs. The evidence for this often appears to be lacking. We have identified a potentially common garnet breakdown reaction responsible for forming staurolite in the Dalradian Leven schists of Scotland that produces distinctive textural and chemical zoning in garnet, but may be difficult to recognize in higher grade conditions. However the presence of cloudy garnet and the irregular zoning patterns linked to abundant quartz inclusions within garnet porphyroblasts in amphibolitefacies pelites may be indicative of this coupled dissolution-reprecipitation reaction. As a consequence a cautious approach to the identification of metamorphic reactions involving garnet might be advised rather than assuming a suite of expected reactions associated with a suite of expected zoning patterns. In the light of our results a fresh look at garnet behaviour may be required.

\section{ACKNOWLEDGEMENTS}

J. Gilleece is thanked for technical assistance. X-ray microtomography is funded by the Scottish Funding Council's Oil and Gas Innovation Centre. Helpful editing by D. Whitney was much appreciated.

\section{REFERENCES}

Albee, A. L. (1965). A petrogenetic grid for the Fe-Mg silicates of pelitic schists. American Journal of Science, 263, 512-536.

Albee, A. L. (1972). Metamorphism of pelitic schists: Reaction relations of chloritoid and staurolite. Geological Society of America, Bulletin, 83, 3249-3268.

Baltatzis, E. (1979). Staurolite-forming reactions in the eastern Dalradian rocks of Scotland. Contributions to Mineralogy and Petrology, 69, 193-200.

Barrow, G. (1893). On an intrusion of muscovite-biotite gneiss in the southeastern Highlands of Scotland and its accompanying metamorphism. Quarterly Journal of the Geological Society, London, 49, 330-358.

Baxter, E. F., Ague, J. J., \& Depaolo, D. J. (2002). Prograde temperature-time evolution in the Barrovian type-locality constrained by Sm/Nd garnet ages from Glen Clova, Scotland. Journal of the Geological Society London, 159, 71-82.

This article is protected by copyright. All rights reserved. 
Bell, T. H. \& Hayward, N. (1991). Episodic metamorphic reactions during orogenesis - the control of deformation partitioning on reaction sites and reaction duration. Journal of Metamorphic Geology, 9, 619-640.

Bell, T. H., \& Johnson, S. E. (1989). Porphyroblast inclusion trails: the key to orogensis. Journal of Metamorphic Geology, 7, 279-310.

Brooks, R., \& Dichiro, G. (1976). Beam hardening in X-ray reconstructive tomography. Physics in Medicine and Biology, 21, 390-398.

Bucher, K., \& Frey, M. (1994). Petrogenesis of metamorphic rocks. Springer-Verlag. Berlin. 318pp.

Caddick, M. J., Konopásek, J., \& Thompson, A. B. (2010). Preservation of garnet growth zoning and the duration of prograde metamorphism. Journal of Petrology, 51, 2327-2347.

Carlson, W. D. (2002). Scales of disequilibrium and rates of equilibration during metamorphism. American Mineralogist, 87, 185-204.

Carlson, W. D. (2006). Rates of Fe, Mg, Mn, and Ca diffusion in garnet. American Mineralogist, 91, 1-11

Carlson, W. D., Hixon, J. D., Garber, J. M., \& Bodnar, R. J. (2015). Controls on metamorphic equilibration: the importance of intergranular solubilities mediated by fluid composition. Journal of Metamorphic Geology, 33, 123-146.

Carlson, W. D., Pattison, D. R. M., \& Caddick, M. J. (2015). Beyond the equilibrium paradigm: How consideration of kinetics enhances metamorphic interpretation. American Mineralogist, 100, 1659-1667.

Carmichael, D. M. (1969). On the mechanism of prograde metamorphic reactions in quartzbearing pelitic rocks. Contributions to Mineralogy and Petrology, 20, 244-267.

Cartwright, I. (1997). Permeability generation and resetting of tracers during metamorphic flow: implications for advection-dispersion models. Contributions to Mineralogy and Petrology, 129, 198-208.

Centrella, S., Austrheim, H., \& Putnis, A. (2015). Coupled mass transfer through a fluid phase and volume preservation during the hydration of granulite: an example from the Bergen Arcs, Norway. Lithos, 236-237, 245-255.

Chernoff, C. B., \& Carlson, W. D. (1997). Disequilibrium for Ca during growth of pelitic garnet. Journal of Metamorphic Geology, 15, 421-438.

Chinner, G. A. (1965). The kyanite isograd in Glen Clova, Angus, Scotland. Mineralogical Magazine, 34, 132-145.

Connolly, J. A. D. (2010). The mechanics of metamorphic fluid expulsion. Elements, 6, 165-172.

Connolly, J. A. D., \& Petrini, K. (2002). An automated strategy for calculation of phase diagram sections and retrieval of rock properties as a function of physical conditions $(0.4 \mathrm{Mb})$. Journal of Metamorphic Geology, 20, 697-708.

This article is protected by copyright. All rights reserved. 
de Béthune, P., Laduron, D., \& Bocquet, J. (1975). Diffusion processes in resorbed garnets. Contributions to Mineralogy and Petrology, 50, 197-204.

Dempster, T. J. (1985). Garnet zoning and metamorphism of the Barrovian Type Area, Scotland. Contributions to Mineralogy and Petrology, 89, 30-38.

Dempster, T. J. (1992). Zoning and recrystallization of phengitic micas: implications for metamorphic equilibration. Contributions to Mineralogy and Petrology, 109, 526-537.

Dempster, T. J., \& Harte, B. (1986). Polymetamorphism in the Dalradian of the central Scottish Highlands. Geological Magazine, 123, 95-104.

Dempster, T., \& Jess, S. A. (2015). Ikaite pseudomorphs in Neoproterozoic Dalradian slates record Earth's coldest metamorphism. Journal of the Geological Society, London, 172, 459464.

Dempster, T. J., Rogers, G., Tanner, P. W. G., Bluck, B. J., Muir, R. J., Redwood, S. D., ... Paterson, B. A. (2002). Timing of deposition, orogenesis and glaciation within the Dalradian rocks of Scotland: constraints from U-Pb ages. Journal of the Geological Society, London, 159, 83-94.

Dempster, T. J., Symon, S., \& Chung, P. (2017). Intergranular diffusion rates from the analysis of garnet surfaces: implications for metamorphic equilibration. Journal of Metamorphic Geology, 35, 585-600.

Dempster, T. J., \& Tanner, P. W. G. (1997). The biotite isograd, Central Pyrenees: a deformationcontrolled reaction. Journal of Metamorphic Geology, 15, 531-548.

Dohmen, R., \& Chakraborty, S. (2003). Mechanism and kinetics of element and isotopic exchange mediated by a fluid phase. American Mineralogist, 88, 1251-1270.

Droop, G. R. T., \& Harte, B. (1995). The effect of Mn on the phase relations of medium-grade pelites: constraints from natural assemblages on petrogenetic grid topology. Journal of Petrology, 36, 1549-1578.

England, P. C., \& Thompson, A. B. (1984). Pressure-Temperature-Time paths of regional metamorphism I. Heat transfer during the evolution of regions of thickened continental crust. Journal of Petrology, 25, 894-928.

Erambert, M., \& Austrheim, H. (1993). The effect of fluid and deformation on zoning and inclusion patterns in poly-metamorphic garnets. Contributions to Mineralogy and Petrology, $115,204-214$.

Etheridge, M. A., Wall, V. J., \& Vernon, R. H. (1983). The role of the fluid phase during regional metamorphism and deformation. Journal of Metamorphic Geology, 1, 205-226.

Farber, K., Caddick, M. J., \& Timm, J. (2014). Controls on solid-phase inclusion during porphyroblast growth: insights from the Barrovian sequence (Scottish Dalradian). Contributions to Mineralogy and Petrology, 168, 1089.

Ferry, J. M. (1994). Overview of the petrological record of fluid-flow during regional metamorphism in northern New England. American Journal of Science, 294, 905-988.

This article is protected by copyright. All rights reserved. 
Ferry, J. M., \& Spear, F. S. (1978). Experimental calibration of the partitioning of Fe and Mg between biotite and garnet. Contributions to Mineralogy and Petrology, 66, 113-117.

Florence, F. P., \& Spear, F. S. (1991). Effects of diffusional modification of garnet growth zoning on P-T path calculations. Contributions to Mineralogy and Petrology, 107, 487-500.

Florence, F. P., \& Spear, F. S. (1993). Influences of reaction history and chemical diffusion on P-T calculations for staurolite schists from the Littleton Formation, northwestern New Hampshire. American Mineralogist, 78, 345-359.

Frost, B. R., \& Frost, C. D. (2014). Essentials of igneous and metamorphic petrology. Cambridge University Press. Cambridge. 303pp.

Ganguly, J. (2010). Cation diffusion kinetics in aluminosilicate garnets and geological applications. Reviews in Mineralogy and Geochemistry, 72, 559-601.

Geiger, C. A., \& Feenstra, A. (1997). Molar volumes of mixing of almandine-pyrope and almandine-spessartine garnets and the crystal chemistry and thermodynamic-mixing properties of the aluminosilicate garnets. American Mineralogist, 82, 571-581.

Groome, W. G., Johnson, S. E., \& Koons, P. O. (2006). The effects of porphyroblast growth on the effective viscosity of metapelitic rocks: implications for the strength of the middle crust. Journal of Metamorphic Geology, 24, 389-407.

Guidotti, C. V. (1970). The mineralogy and petrology of the transition from the lower to upper sillimanite zone in the Oquossoc area, Maine. Journal of Petrology, 11, 277-336.

Hames, W. E., \& Menard T. (1993). Fluid-assisted modification of garnet composition along rims, cracks, and mineral inclusion boundaries in samples of amphibolite facies schists. American Mineralogist, 78, 338-344.

Harris, A. L., Haselock, P. J., Kennedy, M. J., \& Mendum, J. R. (1994). The Dalradian Supergroup in Scotland, Shetland and Ireland. In A. L. Harris, \& W. Gibbons, (Eds) A revised correlation of Precambrian rocks in the British Isles. Geological Society, London, Special Report, 22, 33-53.

Harte, B., \& Hudson, N. F. C. (1979). Pelite facies series and the temperatures and pressures of Dalradian metamorphism in E. Scotland. In A. L. Harris, C. H. Holland, \& B. E. Leake, (Eds.) The Caledonides of the British Isles - reviewed. Geological Society of London Special Publication, 8, 323-337.

Hirsch, D. M., Prior, D. J., \& Carlson, W. D. (2003). An overgrowth model to explain multiple, dispersed high-Mn regions in the cores of garnet porphyroblasts. American Mineralogist, 88, 131-141.

Holdaway, M. J. (2001). Recalibration of the GASP geobarometer in the light of recent garnet and plagioclase activity models and versions of the garnet-biotite geothermometer. American Mineralogist, 86, 1117-1129.

Holdaway, M. J., Guidotti, C. V., Novak, J. M., \& Henry, W. E. (1982). Polymetamorphism in medium- to high-grade pelitic metamorphic rocks, west-central Maine. Geological Society of America, Bulletin, 93, 572-584.

This article is protected by copyright. All rights reserved. 
Holdaway, M. J., Mukhopadhyay, B., \& Dutrow, B. L. (1995). Thermodynamic properties of stoichiometric staurolite $\mathrm{H}_{2} \mathrm{Fe}_{4} \mathrm{Al}_{18} \mathrm{Si}_{8} \mathrm{O}_{48}$ and $\mathrm{H}_{6} \mathrm{Fe}_{2} \mathrm{Al}_{18} \mathrm{Si}_{8} \mathrm{O}_{48}$. American Mineralogist, 80 , 520-533.

Hollister, L. S. (1966). Garnet zoning: an interpretation based on the Rayleigh fractionation model. Science, 154, 1647-1651.

Jamtveit, B., \& Austrheim, H. (2010) Metamorphism: the role of fluids. Elements, 6, 153-158.

Jamtveit, B., Putnis, C. V., \& Malthe-Sørenssen, A. (2009). Reaction induced fracturing during replacement processes. Contributions to Mineralogy and Petrology 157, 127-133.

Karabinos, P. (1985). Garnet and staurolite-producing reactions in chlorite-chloritoid schist. Contributions to Mineralogy and Petrology, 90, 262-275.

Kelly, E. D., Carlson, W. D., \& Ketcham, R. A. (2013). Magnitudes of departures from equilibrium during regional metamorphism of porphyroblastic rocks. Journal of Metamorphic Geology, 31, 981-1002.

Kohn, M. J. (2014). Geochemical zoning in metamorphic minerals. Treatise on Geochemistry, 4, 249-280.

Kohn, M. J, \& Spear, F. (2000). Retrograde net transfer reaction insurance for pressuretemperature estimates. Geology, 28, 1127-1130.

Mahar, E. M., Baker, J. M., Powell, R., Holland, T. J. B., \& Howell, N. (1997). The effect of Mn on mineral stability in metapelites. Journal of Metamorphic Geology, 15, 223-238.

Martin, L. A. J., Ballèvre, M., Boulvais, P., Halfpenny, A., Vanderhaeghe, O., Duchêne, S., \& Deloule, E. (2011). Garnet re-equilibration by coupled dissolution-reprecipitation: evidence from textural, major element and oxygen isotope zoning of 'cloudy' garnet. Journal of Metamorphic Geology, 29, 213-231.

Masters, R. L., \& Ague, J. J. (2005). Regional-scale fluid flow and element mobility in metamorphic zones, Stonehaven, Scotland. Contributions to Mineralogy and Petrology, 150, $1-18$.

Moynihan, D. P., \& Pattison, D. R. M. (2013). An automated method for the calculation of P-T paths from garnet zoning, with application to metapelitic schist from the Kootenay Arc, British Columbia, Canada. Journal of Metamorphic Geology, 31, 525-548.

Mueller, T., Watson, E. B., \& Harrison, T. M. (2010). Application of diffusion data to high temperature earth systems. Reviews in Mineralogy and Geochemistry, 72, 997-1038.

Novak, J. M., \& Holdaway, M. J. (1981). Metamorphic petrology, mineral equilibria, and polymetamorphism in the Augusta quadrangle, south-central Maine. American Mineralogist, 66, 51-69.

Oliver, G. J. H., Chen, F., Buchwaldt, R., \& Hegner, E. (2000). Fast tectonometamorphism and exhumation in the type area of Barrovian and Buchan zones. Geology, 28, 459-462.

This article is protected by copyright. All rights reserved. 
Pattison, D. R. M., De Capitani, C., \& Gaidies, F. (2011), Petrological consequences of variations in metamorphic reaction affinity. Journal of Metamorphic Geology, 29, 953-977.

Pattison, D. R. M., \& Tinkham, D.K. (2009). Interplay between equilibrium and kinetics in prograde metamorphism of pelites: an example from Nelson aureole, British Columbia. Journal of Metamorphic Geology, 27, 249-279.

Phillips, E. R., Key, R. M., Clark, G. C., May, F., Glover, B. W., \& Chacksfield, B. C. (1994). Tectonothermal evolution of the Neoproterozoic Grampian and Appin groups, southwestern Monadhliath Mountains, Scotland. Journal of the Geological Society London, 151, 971-986.

Phillips, E. R., \& Key, R. M. (1992). Porphyroblast-fabric relationships: an example from the Appin Group in the Glen Roy area. Scottish Journal of Geology, 28, 89-101.

Philpotts, A. R., \& Ague, J. J. (2009). Principles of igneous and metamorphic petrology. Cambridge University Press, Cambridge 667pp.

Pollok, K., Lloyd, G. E., Austrheim, H., \& Putnis, A. (2008). Complex replacement patterns in garnets from Bergen Arcs eclogites: a combined EBSD and analytical TEM study. Chemie der Erde, 68, 177-191.

Putnis, A., \& Austrheim, H. (2010). Fluid-induced processes: metasomatism and metamorphism. Geofluids, 10, 254-269.

Putnis, A., \& John, T. (2010). Replacement processes in the Earth's crust. Elements, 6, 159-164.

Putnis, A., \& Putnis, C. V. (2007). The mechanism of reequilibration of solids in the presence of a fluid phase. Journal of Solid State Chemistry, 180, 1783-1786.

Putnis, C. V., Tsukamoto, K., \& Nishimura, Y. (2005). Direct observation of pseudomorphism: compositional and textural evolution at a fluid-solid interface. American Mineralogist, 90 , 1909-1912.

Pyle, J. M., \& Spear, F. S. (2003) Yttrium zoning in garnet: coupling of major and accessory phases during metamorphic reactions. American Mineralogist, 88, 708.

Reyes, C. A. R., Alarcón, O. M. C., \& Takasu, A. (2008). A new interpretation for the garnet zoning in metapelitic rocks of the Silgará Formation, southwestern Santander Massif, Columbia. Earth Science Research Journal, 12, 7-30.

Richardson, S. W., \& Powell, R. (1976). Thermal causes of the Dalradian metamorphism in the central Highlands of Scotland. Scottish Journal of Geology, 12, 237-268.

Ríos, C. A., Castellanos, O. M. \& Takasu, A. (2010) X-ray color maps of the zoned garnets from Silgará Formation metamorphic rocks, Santander Massif, Eastern Cordillera (Colombia). Earth Sciences Research Journal, 14, 161-172.

Robyr, M., Darbellay, B., \& Baumgartner, L. P. (2014). Matrix-dependent garnet growth in polymetamorphic rocks of the Sesia zone, Italian Alps. Journal of Metamorphic Geology, 32, 3-24.

This article is protected by copyright. All rights reserved. 
Rubie, D. C. (1986). The catalysis of mineral reactions by water and restrictions on the presence of aqueous fluids during metamorphism. Mineralogical Magazine, 50, 399-415.

Ruiz-Agudo, E., Putnis, C. V., \& Putnis, A. (2014). Coupled dissolution and precipitation at mineral-fluid interfaces. Chemical Geology, 383, 132-146.

Skelton, A. D. L., Graham, C. M., \& Bickle, M. J. (1995). Lithological and structural controls on regional-scale fluid flow patterns during greenschist facies metamorphism of the Dalradian of SW Scottish Highlands. Journal of Petrology, 35, 563-586.

Spear, F. S. (1988). Metamorphic fractional crystallization and internal metasomatism by diffusional homogenization of zoned garnets. Contributions to Mineralogy and Petrology, 99, 507-517.

Spear, F. S. (1991). On the interpretation of peak metamorphic temperatures in light of garnet diffusion during cooling. Journal of Metamorphic Geology, 9, 379-388.

Spear, F. S. (2014). The duration of near-peak metamorphism from diffusion modeling of garnet zoning. Journal of Metamorphic Geology, 32, 903-914.

Spear, F. S., \& Cheney, J. T. (1989). A petrogenetic grid for pelitic schists in the system $\mathrm{SiO}_{2}-$ $\mathrm{Al}_{2} \mathrm{O}_{3}-\mathrm{FeO}-\mathrm{MgO}-\mathrm{K}_{2} \mathrm{O}-\mathrm{H}_{2} \mathrm{O}$. Contributions to Mineralogy and Petrology, 101, 149-164.

Spear, F. S., Kohn, M. J., Florence, F. P., \& Menard, T. (1990). A model for garnet and plagioclase growth in pelitic schists: implications for thermobarometry and P-T path determinations. Journal of Metamorphic Geology, 8, 683-696.

Thompson, J. B., (1957). The graphical analysis of mineral assemblages in pelitic schists. American Mineralogist, 42, 842-858.

Thompson, A. B. (1976). Mineral reactions in pelitic rocks. 1. Prediction of P-T-X (Fe-Mg) relations. American Journal of Science, 276, 401-424.

Thompson, A. B., Tracy, R. J., Lyttle, P. T., \& Thompson, J. B., Jr. (1977). Prograde reaction histories deduced from compositional zonation and mineral inclusions in garnet from the Gassetts Schist, Vermont. American Journal of Science 277, 1152-1167.

Tracy, R. J., Robinson, P., \& Thompson, A. B. (1976). Garnet composition and zoning in the determination of temperature and pressure of metamorphism, central Massachusetts. American Mineralogist, 61, 762-775.

Tracy, R. J. (1982). Compositional zoning and inclusions in metamorphic minerals. Reviews in Mineralogy and Geochemistry, 10, 355-397.

Tuccillo, M. E., Essene, E. J., \& van der Pluijm, B. A. (1990). Growth and retrograde zoning in garnets from high-grade metapelites: Implications for pressure-temperature paths. Geology, 18, 839-842.

Vernon, R. H., White, R. W., \& Clarke, G. L. (2008) False metamorphic events inferred from misinterpretation of microstructural evidence and $P$ - $T$ data. Journal of Metamorphic Geology, 26, 437-449.

This article is protected by copyright. All rights reserved. 
Whitney, D. L. (1996). Garnets as open systems during regional metamorphism. Geology, 24, 147-150.

Whitney, D. L., Cooke, M. L., \& Du Frane, A. (2000) Modeling of radial microcracks at corners of inclusions in garnet using fracture mechanics. Journal of Geophysical Research, 105, 28432853.

Whitney, D. L., \& Evans, B. W. (2010) Abbreviations for names of rock-forming minerals. American Mineralogist, 95, 185-187.

Whitney, D. L., \& Ghent, E. D. (1993). Prograde reactions and garnet zoning reversals in staurolite schist, British Columbia: significance for thermobarometric interpretations: Journal of Metamorphic Geology, 11, 779-788.

Whitney, D. L., Mechum, T. A., Dilek, Y., \& Kuehner, S. M. (1996). Modification of garnet by fluid infiltration during regional metamorphism in garnet through sillimanite-zone rocks, Duchess County, New York. American Mineralogist, 81, 696-705.

Wing, B. A., \& Ferry, J. M. (2002). Three dimensional geometry of metamorphic fluid flow during Barrovian regional metamorphism from an inversion of combined petrologic and stable isotopic data. Geology, 30, 639-642.

Yang, P., \& Rivers, T. (2001). Chromium and manganese zoning in pelitic garnet and kyanite: spiral, overprint, and oscillatory (?) zoning patterns and the role of growth rate. Journal of Metamorphic Geology, 19, 455-474.

Yardley, B. W. D. (1977). An empirical study of diffusion in garnet. American Mineralogist, 62, 793-800.

Yardley, B. W. D. (2009). The role of water in the evolution of the continental crust. Journal of the Geological Society, London, 166, 585-600.

Zeh, A. (2006). Calculation of garnet fractionation in metamorphic rocks, with application to a flat-top, Y-rich garnet population from the Ruhla crystalline complex, Central Germany. Journal of Petrology, 47, 2335-2356.

Zwart, H. J. (1962). On the determination of polymetamorphic mineral associations, and its application to the Bosost area (Central Pyrenees). Geologische Rundschau, 52, 38-65.

\section{SUPPORTING INFORMATION}

Additional Supporting Information may be found online in the supporting information tab for this article.

Figure S1. MP4 movie showing 3D reconstruction of garnet porphyroblast surface from X-ray computed microtomography. Smooth areas represent euhedral garnet surfaces, irregular areas of the surface containing extensive pits and hollows are characterized by abundant partially enclosed quartz and plagioclase matrix grains.

This article is protected by copyright. All rights reserved. 


\section{FIGURE LEGENDS}

Figure 1. Thin section photomicrographs of staurolite schist and garnet porphyroblasts within staurolite-bearing and staurolite-free schists. (a) composite image shows typical position of staurolite (st) adjacent to garnet porphyroblasts (sample GR01), arrow indicates the orientation of the muscovite-rich S2 fabric; (b) shows typical garnet porphyroblast from staurolite-free schist (sample GR05); (c) shows "cloudy" garnet from staurolite-bearing schist (sample GR01); and (d) shows syntectonic garnet porphyroblast from schist with very low modal proportions of staurolite (sample GR03).

Figure 2. (a) Plot showing the spatial relationship between the position of staurolite and proximity to the nearest garnet porphyroblast in each of the three staurolite-bearing schists (GR01, GR03, GR04). Also shown is the theoretical distribution of staurolite based on random positions within the matrix of thin section GR01. (b) Rose diagrams for each of the staurolitebearing samples showing the angular relationship between the centre of staurolite that are within $400 \mu \mathrm{m}$ of the nearest garnet porphyroblast and the centre of the garnet. Angular relationships are measured relative to the $90^{\circ}-270^{\circ}$ orientation of the micaceous fabric.

Figure 3. Plot showing the modal abundance of cloudy garnet vs the modal abundance of staurolite. Dashed line illustrates the theoretical proportions of staurolite to cloudy garnet associated with an inferred reaction (see text for details).

Figure 4. (a) and (b) 3D triangular-meshed surface view from X-ray tomography of a garnet porphyroblast, porphyroblast is rotated into two positions and illustrates both inclusion poor surfaces (a) and inclusion-rich surfaces (b), in both instances overall outline shapes of the porphyroblast are euhedral. Cartoon crystal lattice models show porphyroblast orientations. Movie of rotating porphyroblast presented in Figure S1; (c) Backscattered electron image of garnet porphyroblast surface showing areas of perfectly planer surface and areas with localized micro-scale pitting (marked by arrow). All garnet from sample GR01.

Figure 5. Images showing the nature of cloudy garnet. (a) photomicrograph of transmitted light view of aligned micro-inclusions within garnet. Area of inclusion-free "clear" garnet to lower left of image. Note transitional nature of the contact; (b) Backscattered electron image of fractured surface of cloudy garnet showing abundant micropores; (c) Backscattered electron image of polished thin section showing fine scale pitting on the surface adjacent to quartz-filled (dark BSE signal) fracture within a garnet porphyroblast; and (d) Transmitted light photomicrograph of dark cloudy garnet (from same area adjacent to fracture as image (c). All garnet from sample GR01.

This article is protected by copyright. All rights reserved. 
Figure 6. (a) Plot showing the proportions of quartz inclusions within the cloudy and clear portions of eleven individual garnet porphyroblasts in sample GR01; (b) Backscattered electron image of abundant large quartz inclusions (dark) in cloudy garnet. Note inclusion have finely "scalloped" boundaries; (c \& d) Backscattered electron image of garnet porphyroblast showing areas of cloudy (cl) garnet marked by larger quartz inclusions; (e) Transmitted light photomicrographs showing relationship between the cloudy (dark) garnet and both fractures and larger quartz inclusions.

Figure 7. Chemical characteristics of garnet in staurolite-free sample (GR05). (a) X-ray map showing Mn concentration (orange colours show high Mn content) superimposed on BSE image of garnet porphyroblasts in sample GR05. Location of compositional zoning profile marked by line A-B; (b) Compositional zoning within garnet porphyroblast along line A-B showing variation in garnet end-member compositions.

Figure 8. Chemical characteristics of garnet in staurolite-bearing sample (GR01). (a) BSE image showing location of compositional zoning profile A-B, and areas of cloudy garnet (cl) outlined in dashed red lines; (b) Transmitted light image of the garnet shown in (a) showing dark areas of cloudy garnet; (c) Composite X-ray map showing Mn distribution (green), Ca-distribution (orange) superimposed on BSE image of porphyroblast; (d) Composite X-ray map showing Mgdistribution (red-high, yellow-low)) superimposed on BSE image of porphyroblast. Note that vertical and horizontal colour variations are artifacts of combining four individual maps to produce the composite image; (e) Composite X-ray map showing Ca-distribution (red-high; yellow-low) superimposed on BSE image of porphyroblast; (f) Compositional zoning within garnet porphyroblast along line $\mathrm{A}-\mathrm{B}$, showing variation in garnet end-member compositions. Areas of cloudy garnet along profile are marked by positions of grey bands.

Figure 9. Composition traverses across cloudy-clear garnet junctions in porphyroblasts from sample GR01. (a) BSE image showing locations of traverse A-B. Approximate position of junction (transitional) between clear and cloudy garnet shown by dashed line; (b) Compositional zoning along traverse A-B showing variation in garnet end-member compositions; (c) BSE image showing locations of traverse C-D. Approximate position of junction (transitional) between clear and cloudy garnet shown by dashed line; (d) Compositional zoning along traverse A-B showing variation in garnet end-member compositions.

Table 1. Modal mineralogy of samples of Leven schist. Cloudy Grt (\%) represents the percentage of cloudy garnet in the total amount of garnet present. Mineral abbreviations follow Whitney \& Evans (2010).

This article is protected by copyright. All rights reserved. 


\begin{tabular}{|r|r|r|r|r|r|}
\hline & GR01 & GR02 & GR03 & GR04 & GR05 \\
\cline { 2 - 6 } Grt (clear) & 4.4 & 8.2 & 5.1 & 3.8 & 6.8 \\
\hline Grt (cloudy) & 6.2 & 0 & 2.8 & 2.5 & 0.2 \\
\hline $\mathrm{Bt}$ & 11.8 & 17.3 & 12.1 & 7.8 & 14.7 \\
\hline $\mathrm{Ms}$ & 38.4 & 33.5 & 29.4 & 34.2 & 38.1 \\
\hline $\mathrm{Pl}$ & 12.3 & 10.4 & 21.1 & 15.9 & 9.6 \\
\hline $\mathrm{Qz}$ & 30.8 & 28.9 & 27.8 & 29.8 & 28 \\
\hline $\mathrm{St}$ & 3.7 & 0 & 0.6 & 0.9 & 0 \\
\hline Chl & 3.3 & & 0.9 & 4.1 & 0.5 \\
\hline Opq & 0.9 & 1.6 & 0.9 & 1.2 & 0.5 \\
\hline & & & & & \\
\hline cloudy Grt (\%) & 58.5 & 0 & 35.4 & 39.7 & 2.9 \\
\hline
\end{tabular}

This article is protected by copyright. All rights reserved. 


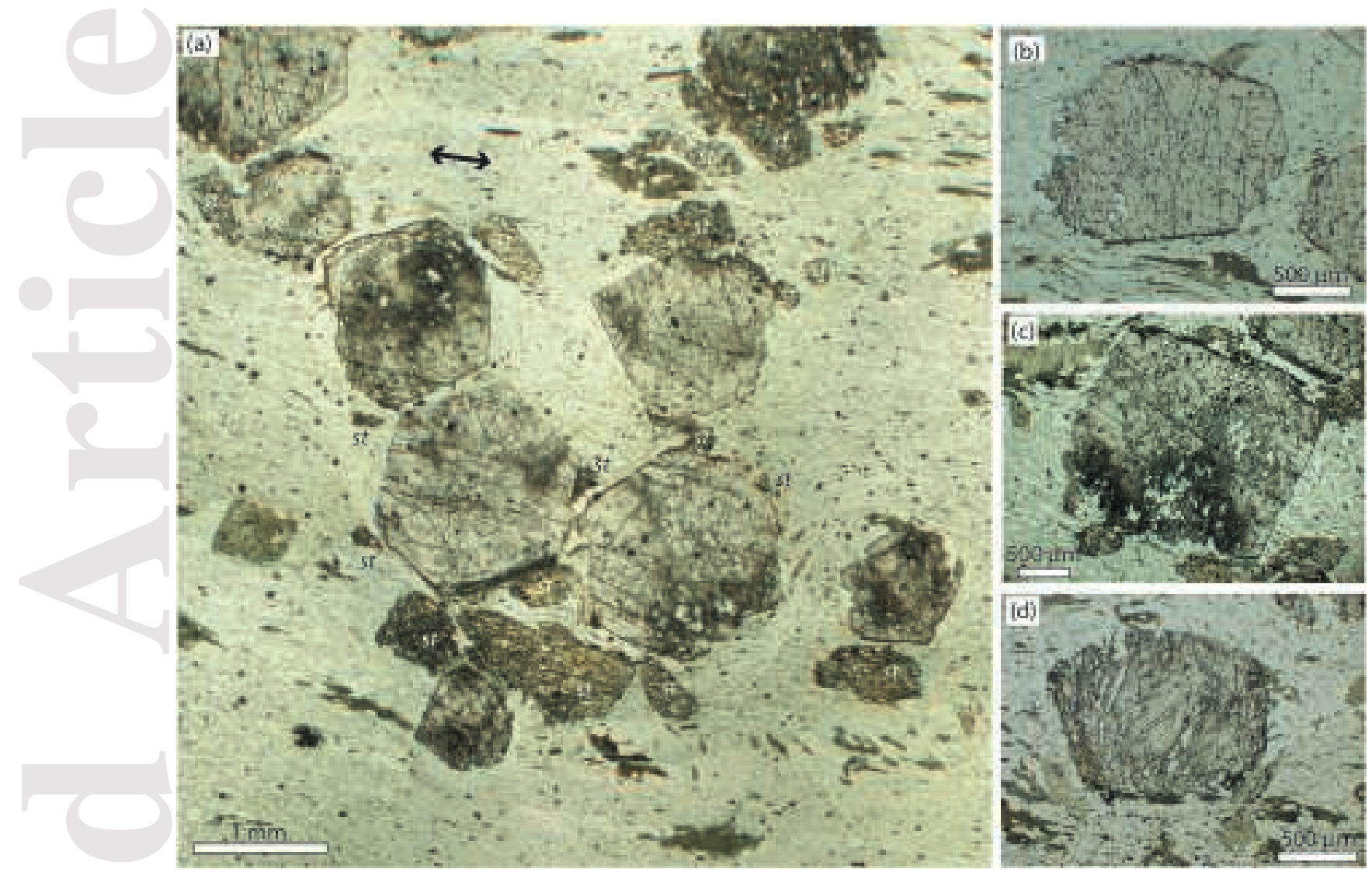

This article is protected by copyright. All rights reserved. 
(a)

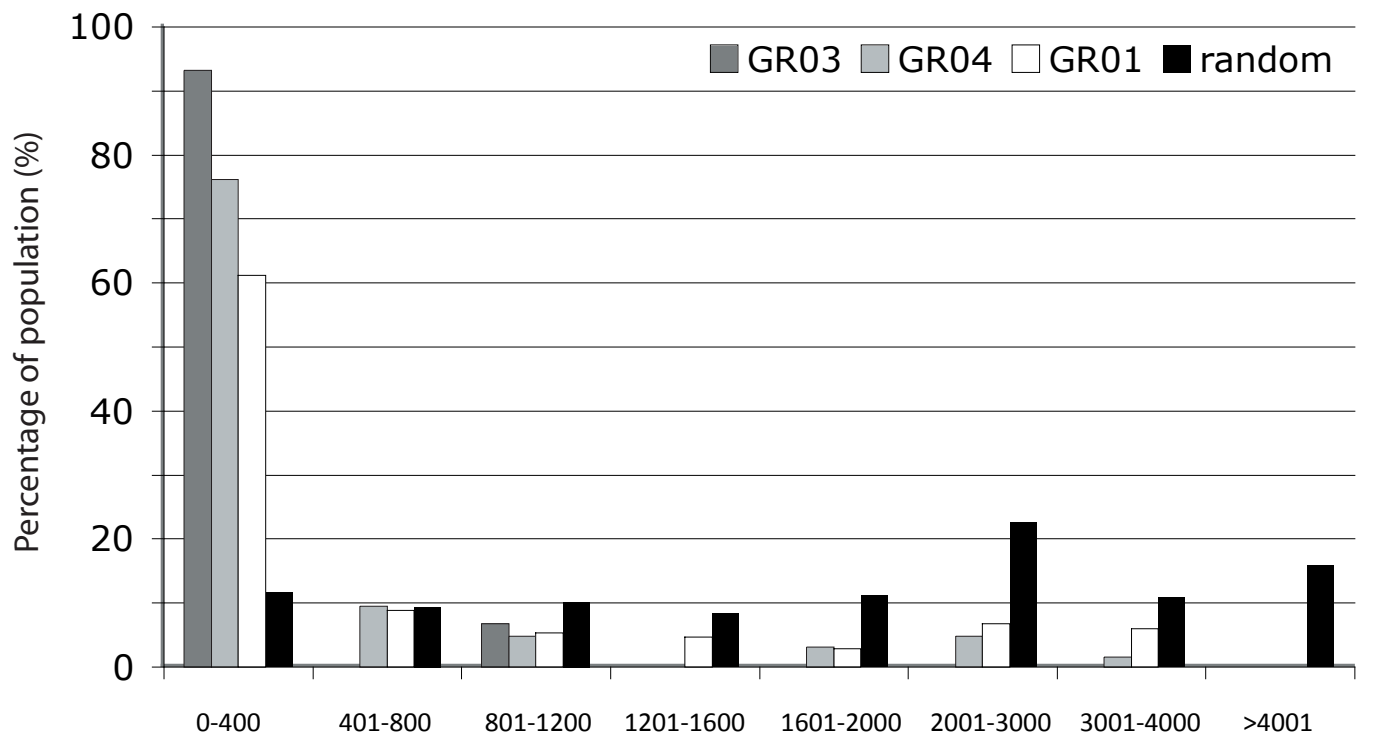

(b)
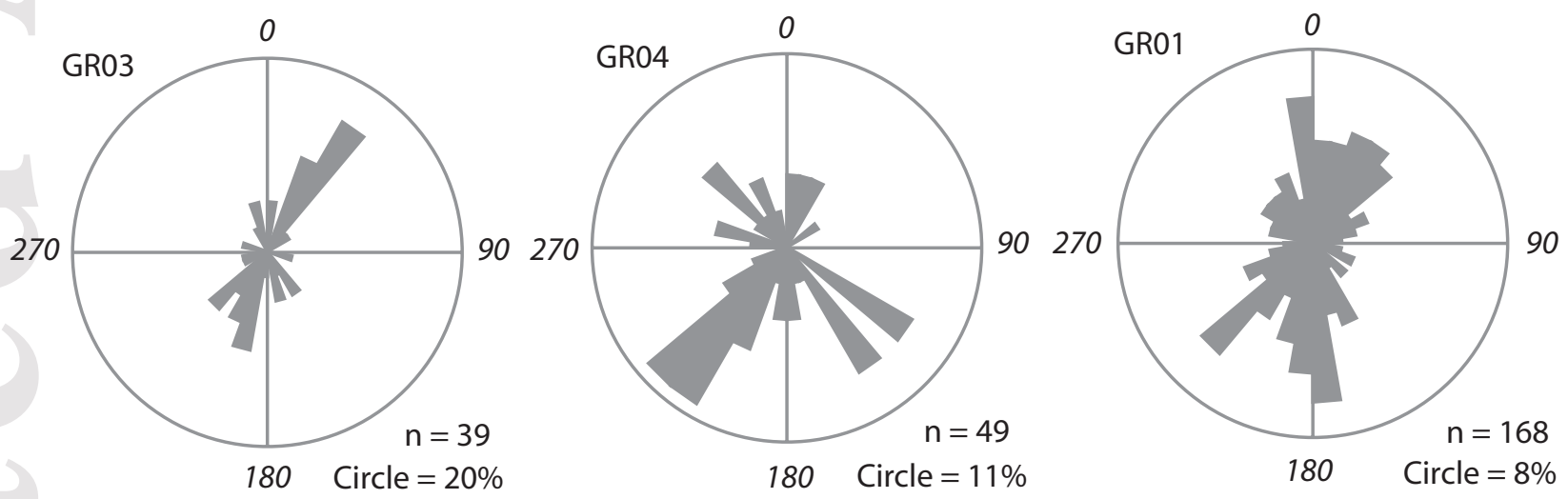

This article is protected by copyright. All rights reserved. 


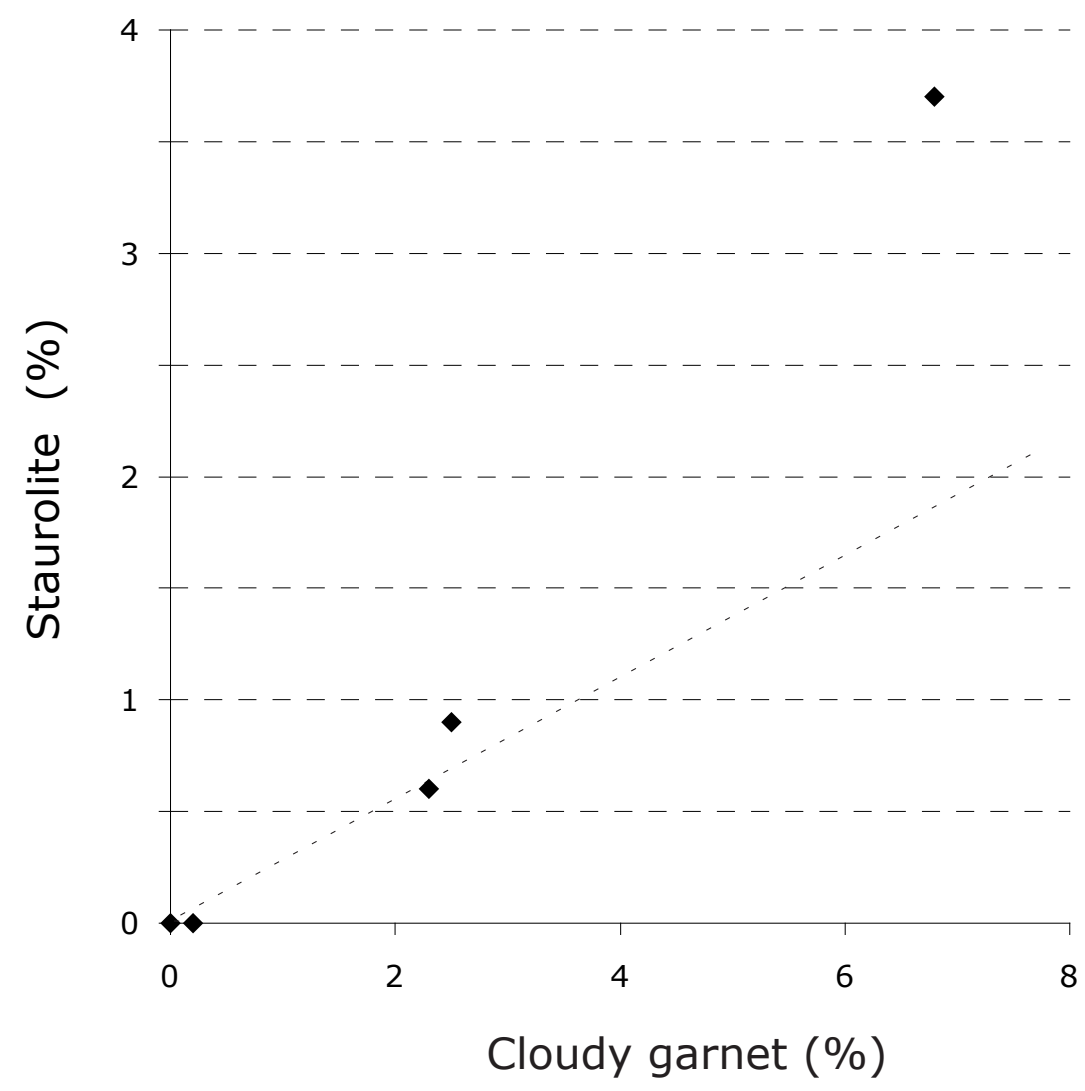

This article is protected by copyright. All rights reserved. 


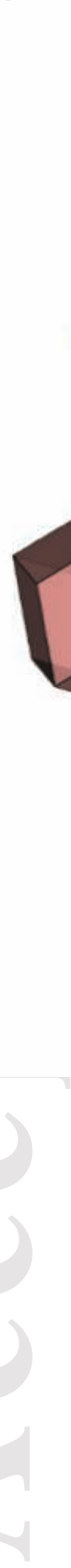

(a)
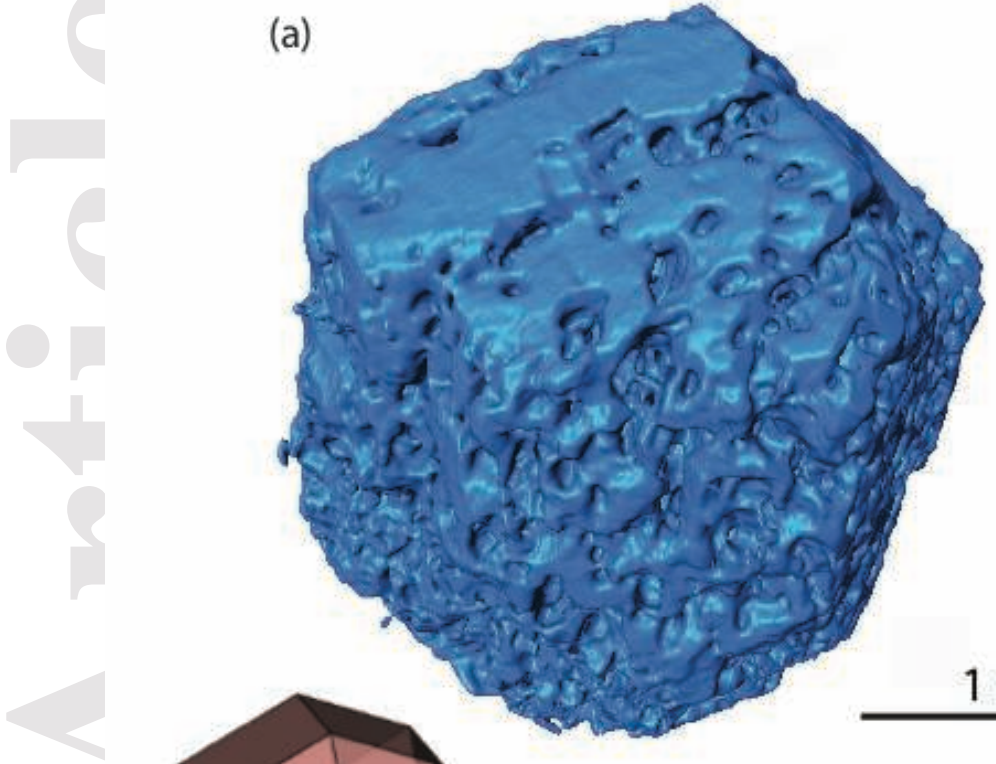

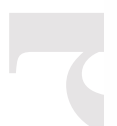

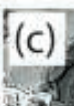

(b)

)

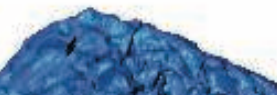

$1 \mathrm{~mm}$
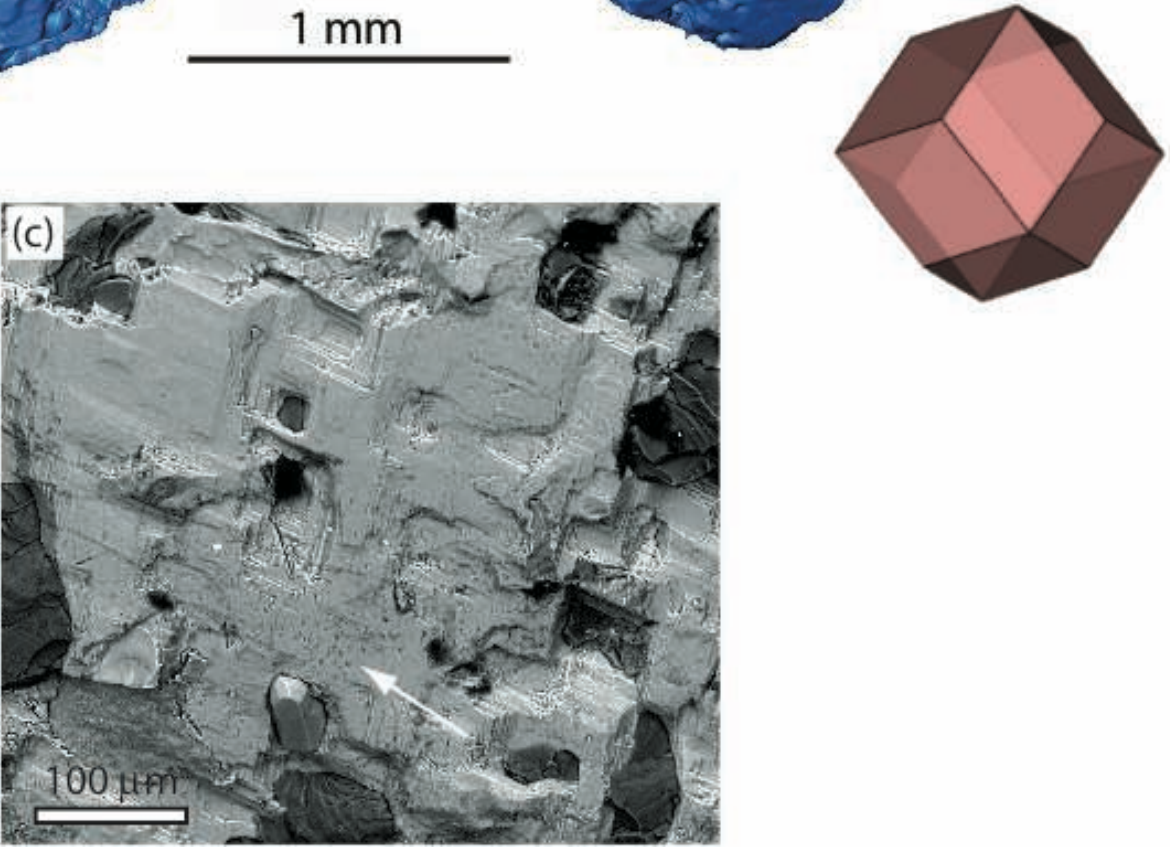

This article is protected by copyright. All rights reserved. 

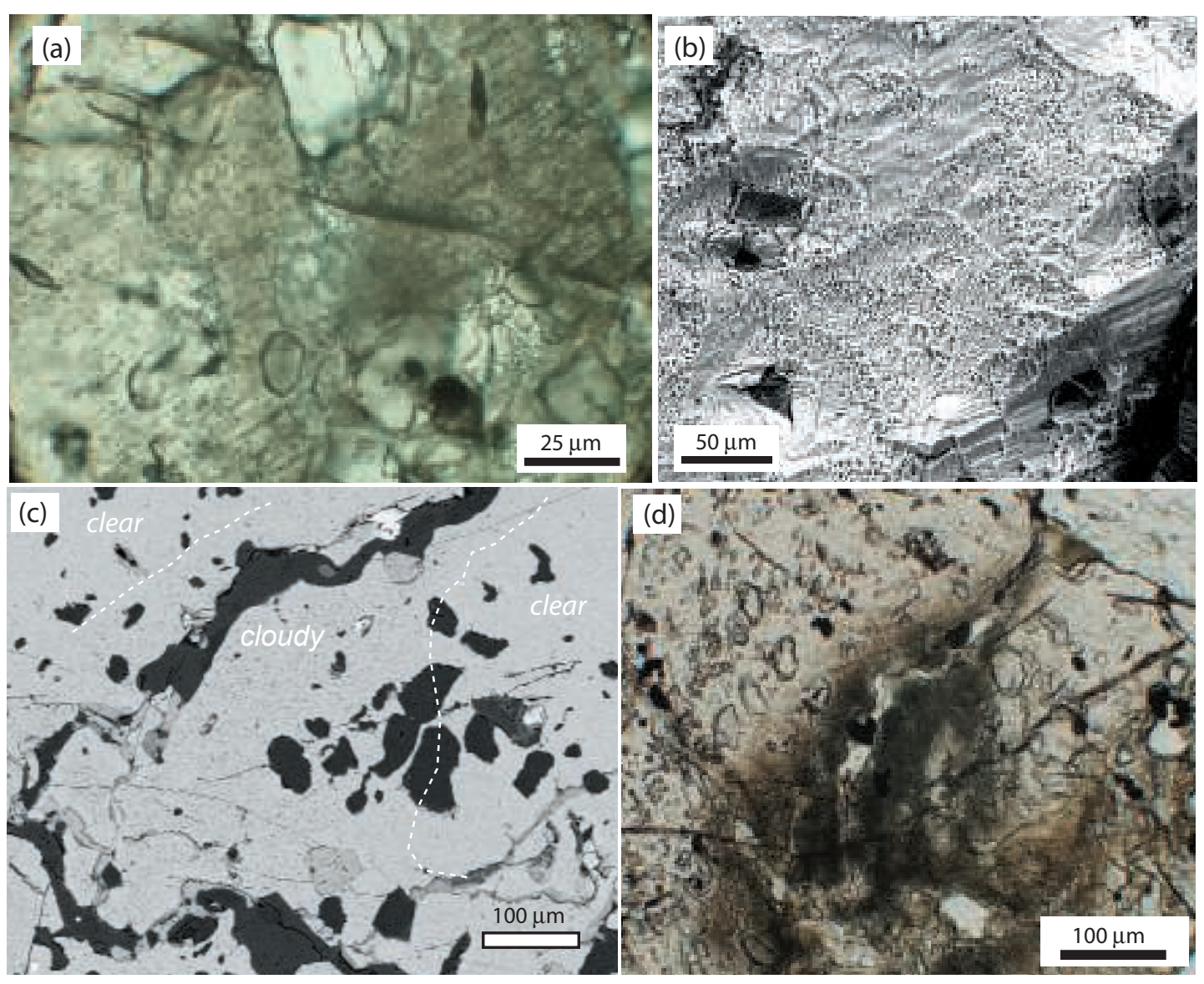

This article is protected by copyright. All rights reserved. 

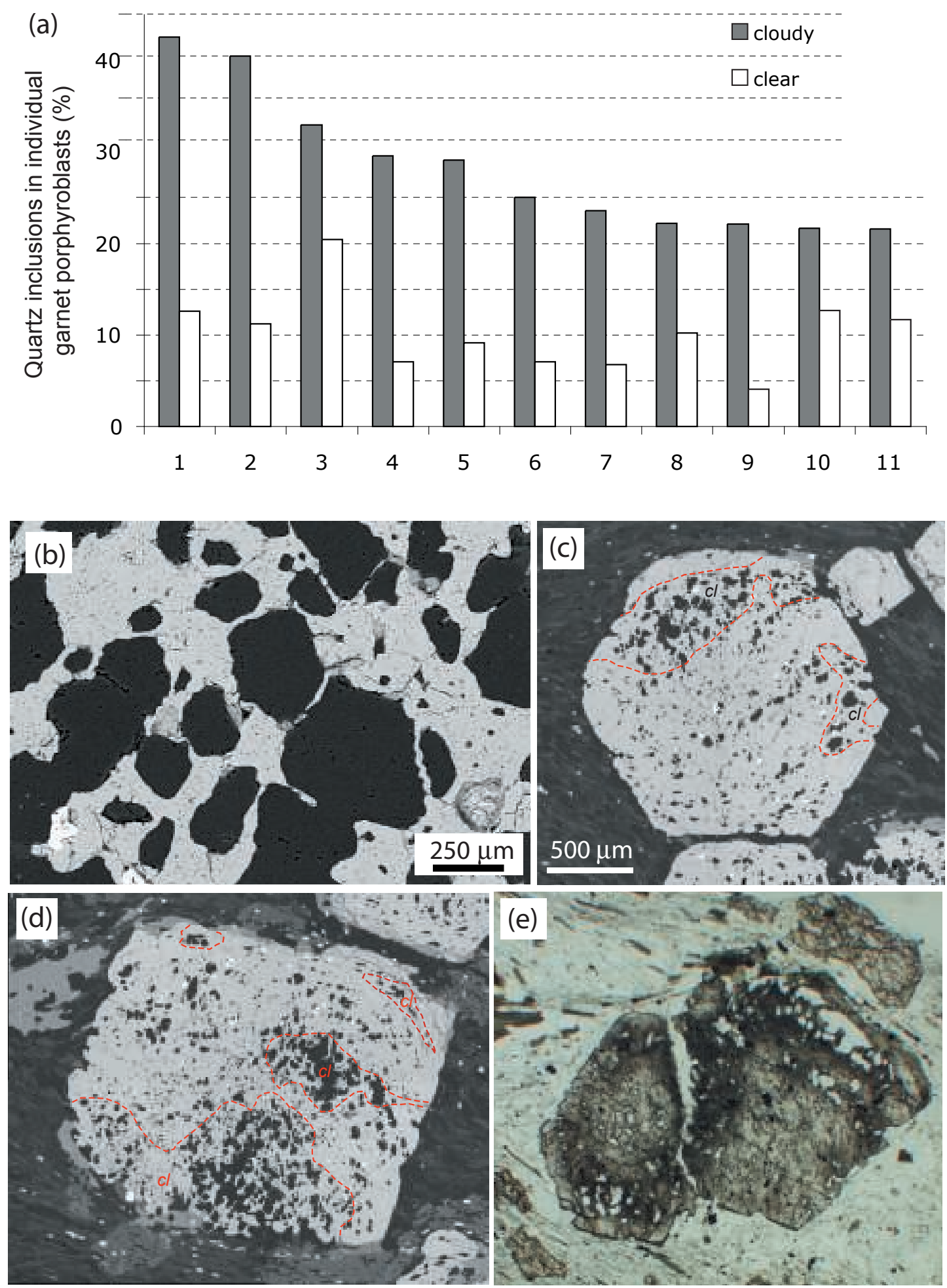

This article is protected by copyright. All rights reserved. 

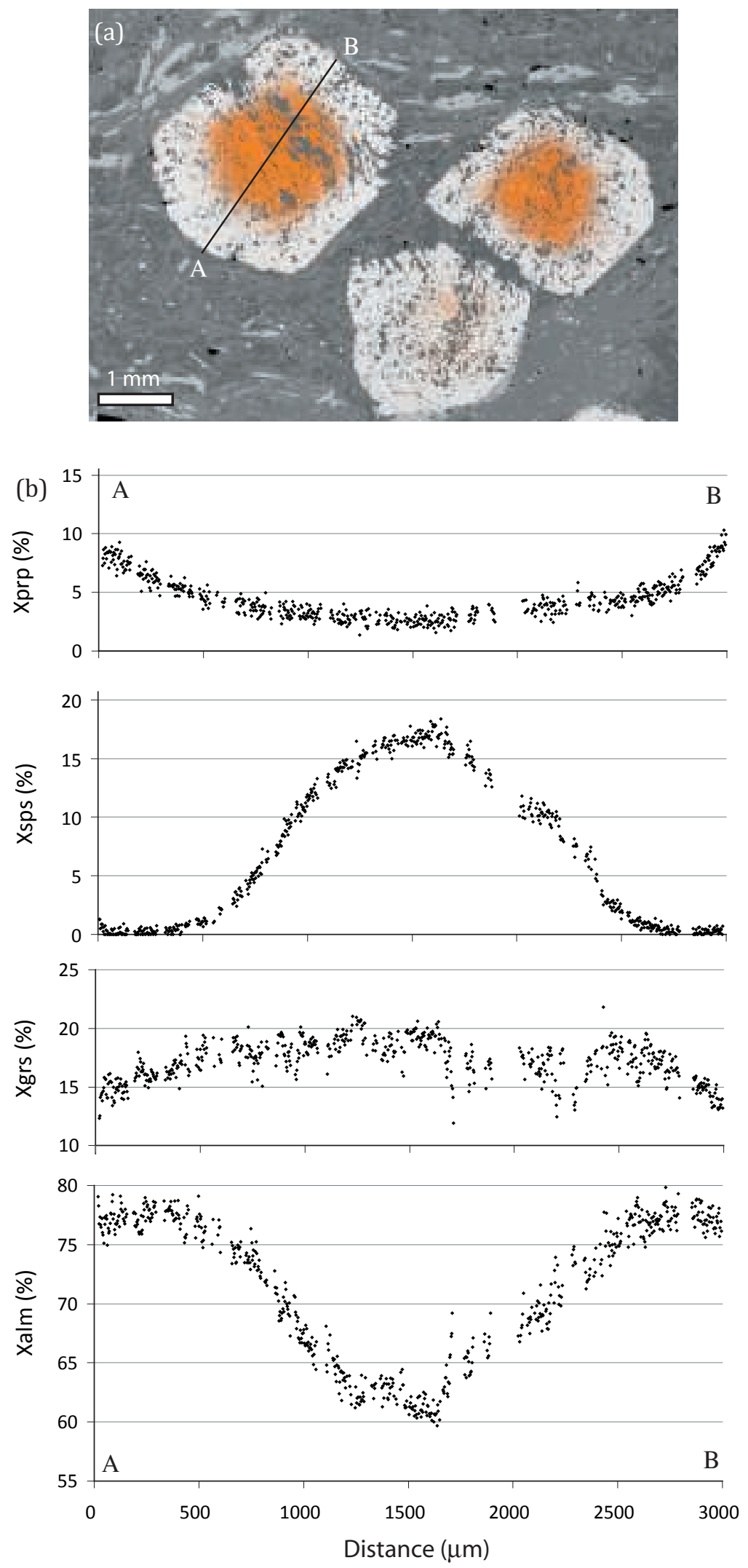

This article is protected by copyright. All rights reserved. 

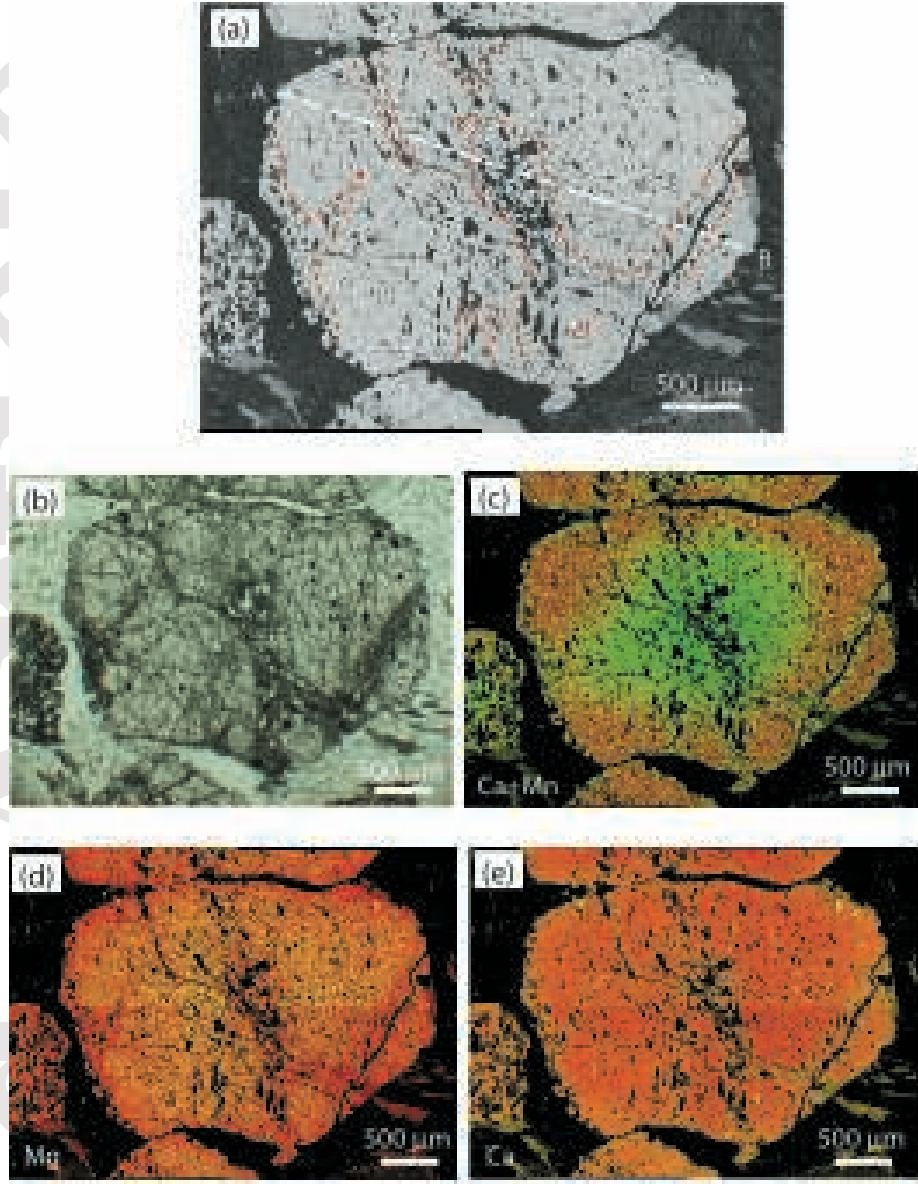
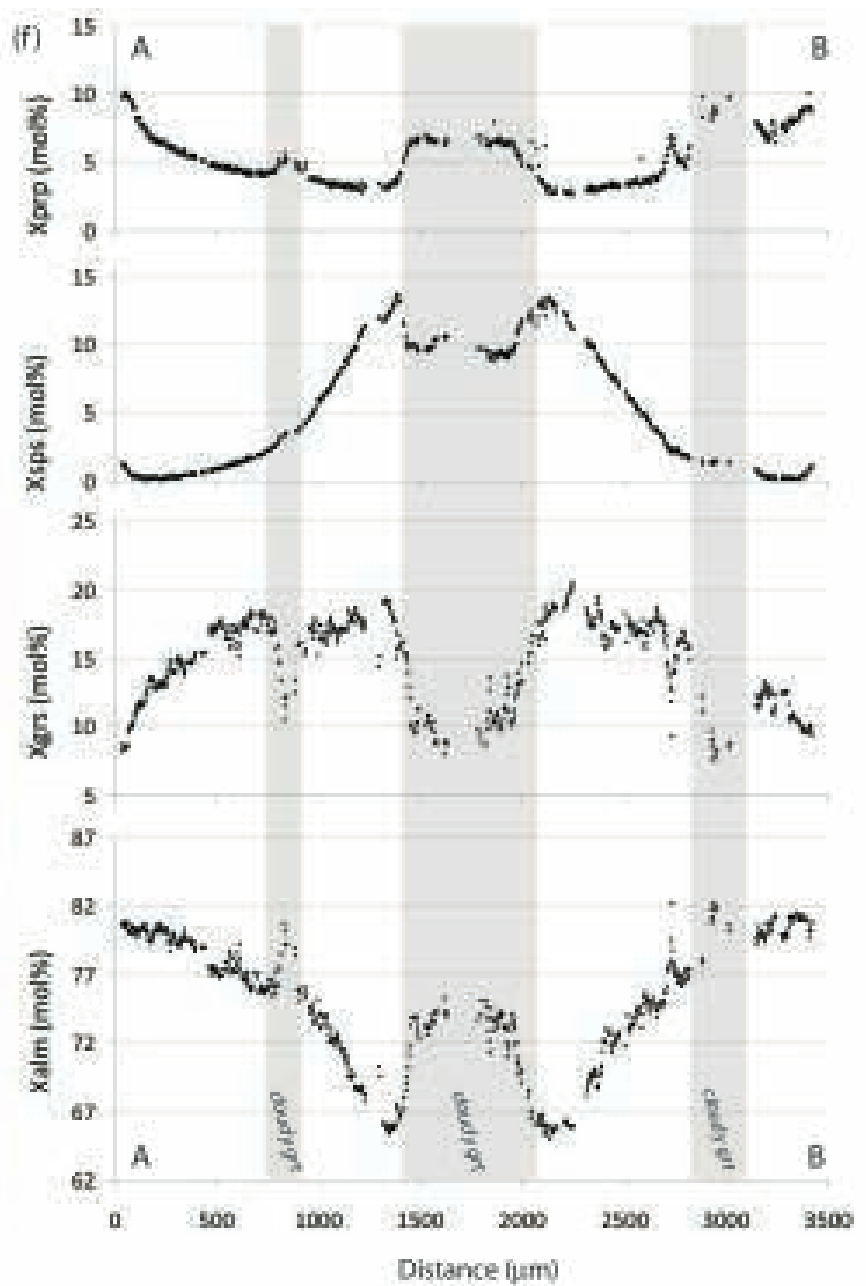

This article is protected by copyright. All rights reserved. 

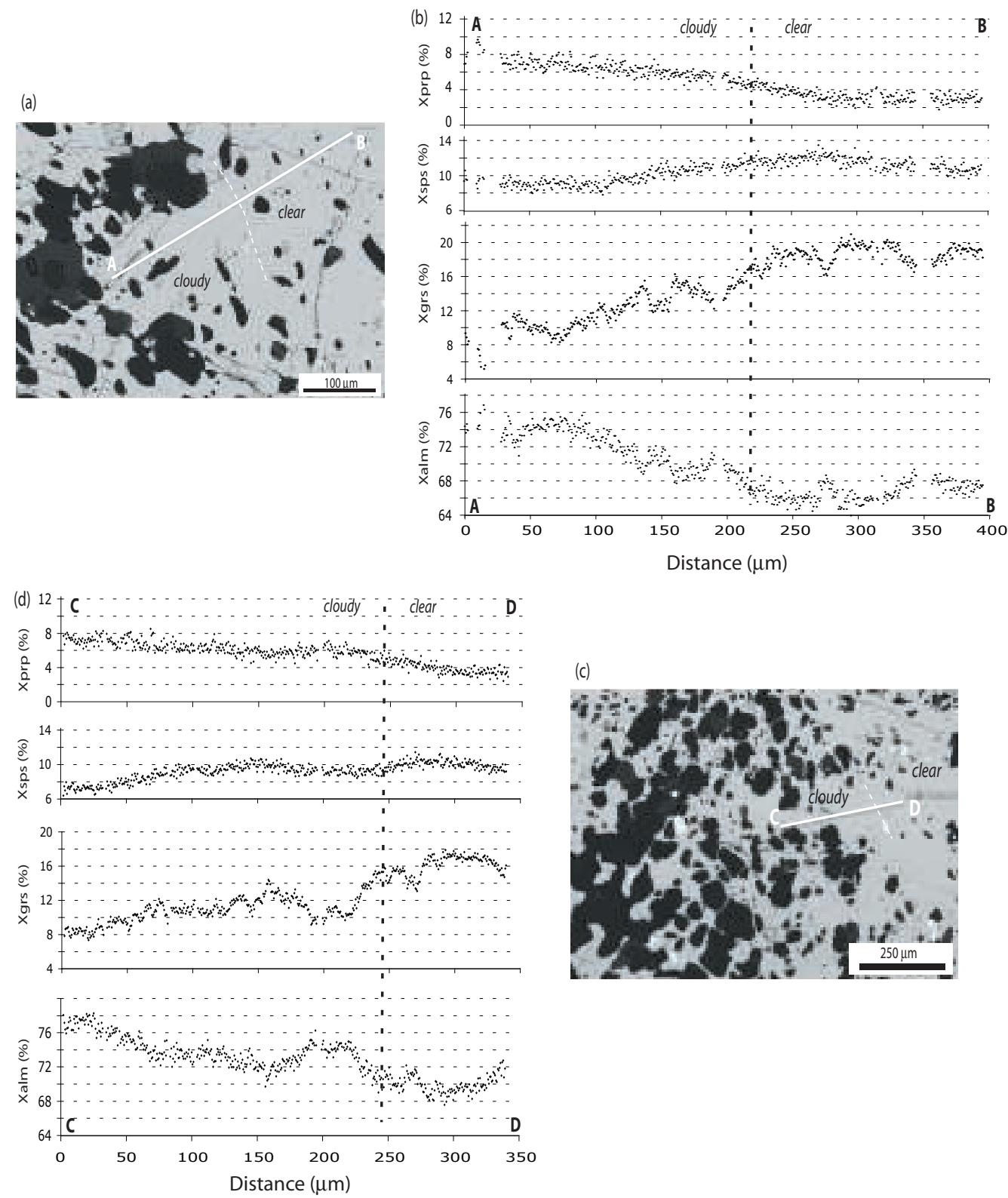

This article is protected by copyright. All rights reserved. 